\title{
ORIGEM E EVOLUÇÃO DAS ROCHAS METAVULCÂNICAS E METAPLUTÔNICAS DA REGIÃO DE ARENÓPOLIS (GO)
}

\author{
MÁRCIO MARTINS PIMENTEL* e REINHARDT ADOLFO FUCK*
}

\begin{abstract}
The lithological and geochemical characteristics of metavolcanic and associated metaplutonic rocks of the Arenópolis volcano-sedimentary sequence, in southwestern Goiás, Brazil, suggest an origin in a tectonic setting similar to modern volcanic arcs in a subduction zone environment. The mafic rocks are geochemically similar to the low-K tholeiites, typical fo the early stages of development of recent island arcs, and the intermediate to felsic metavolcanic and metapyroclastic rocks are calc-alkaline. A multi-arc model is proposed for the geotectonic evolution of the Upper Proterozoic terranes that include the volcano-sedimentary sequence, in southwestern Goiás.
\end{abstract}

INTRODUÇÃO Os terrenos pré-cambrianos situados a oeste do importante lineamento de Moiporá-Novo Brasil, a sudoeste de Goiás (Fig. 1), são caracterizados pela ocorrência de diversas seqüências de rochas metavulcânicas e metassedimentares, como as que estão expostas nas regiões de Bom Jardim de Goiás (Fragomeni \& Costa 1976, Marques et al. 1980, Seer 1985), Arenópolis (Ianhez et al. 1983, Ianhez et al. 1984, Pimentel 1985, Pimentel \& Fuck 1986) e Amorinópolis-Iporá (Ianhez et al. 1983, Ianhez et al. 1984, Bernasconi 1983, Bernasconi 1984). Ocorrências de rochas metavulcânicas são também conhecidas nas regiões de Jaupaci, Israelândia, Fazenda Nova, Ivolândia e Jussara. Essas seqüências são constituídas por rochas metavul, cânicas e metapiroclásticas máficas e félsicas e por rochß̧s metassedimentares de natureza variada, englobando metagrauvacas, micaxistos pelíticos, quartzitos, conglomerados, mármores e metacherts. Corpos plutônicos máfico-ultramáficos são conhecidos nas seqüências de Arenópolis e de Amorinópolis-Iporá.

Terrenos graníticos e gnáissicos constituem as áreas situadas entre as diversas seqüências vulcano-sedimentares. Nos trabalhos de Pena \& Figueiredo (1972), Faria et al. (1975), Schobbenhaus Filho et al. (1975), Bernasconi (1983) e Bernasconi (1984), esse conjunto de rochas graníticas e gnáissicas foi incluído no chamado Complexo Basal Goiano. Entretanto, dados isotópicos de $\mathrm{Rb}-\mathrm{Sr}$ de alguns corpos graníticos (Ianhez et al. 1983, Pimentel et al. 1985) indicam, através de diagramas isocrônicos, idades brasilianas. Idades de $568 \pm 10 \mathrm{Ma}, 564 \pm 5 \mathrm{Ma}$ e $524 \pm 16 \mathrm{Ma}$ (idade convencional $\mathrm{Rb}-\mathrm{Sr}$ ) foram obtidas, respectivamente, nos corpos graníticos do Rio Caiapó, da Serra do Iran e da Serra Negra, na região de Arenópolis-Piranhas. A isócrona referente ao granito do Rio Caiapó foi modificada com a inclusão de um ponto analítico com razão ${ }^{87} \mathrm{Rb} /{ }^{86} \mathrm{Sr}$ mais elevada, obtido por Ianhez et al. (1983) em amostra do mesmo corpo granítico, passando a indicar uma idade um pouco mais antiga, de $585 \pm 12 \mathrm{Ma}$ com razão inicial ${ }^{87} \mathrm{Sr} /{ }^{86} \mathrm{Sr}$ igual a 0,70382 . Barbour et al. (1975) verificaram idade de $467 \pm 10 \mathrm{Ma}$ e razão inicial de 0,705 para rochas gnáissicas da região de Santa Fé, a noroeste de Jussara. As baixas razões iniciais encontradas também nos corpos graníticos do Rio Caiapó e da Serra do Iran $(0,70382$ e 0,70499 , respectivamente) sugerem que parte significativa desses terrenos graníticos tenha sido formada e adicionada à crosta durante o Proterozóico Superior.
O granito do Rio Caiapó constitui um corpo de dimensões batolíticas situado entre Arenópolis e Iporá, e engloba rochas porfiríticas levemente deformadas, que variam de gabros a granitos, passando por quartzo dioritos, quartzo monzodioritos, quartzo monzonitos e granodioritos. Esse corpo mostra afinidades calcialcalinas, assemelhando-se aos batólitos característicos de arcos magmáticos mais jovens, desenvolvidos em zonas de confronto de placas litosféricas. Os corpos da Serra do Iran e da Serra Negra, por outro lado, mostram trama isotrópica, caráter pós-tectônico e tendência alcalina; também apresentam teores mais elevados em $\mathrm{SiO}_{2}, \mathrm{~K}_{2} \mathrm{O}$ e $\mathrm{Rb}$, e foram introduzidos durante as fases finais da evolução magmática da região, provavelmente em uma situação pós-colisional (Pimentel 1985).

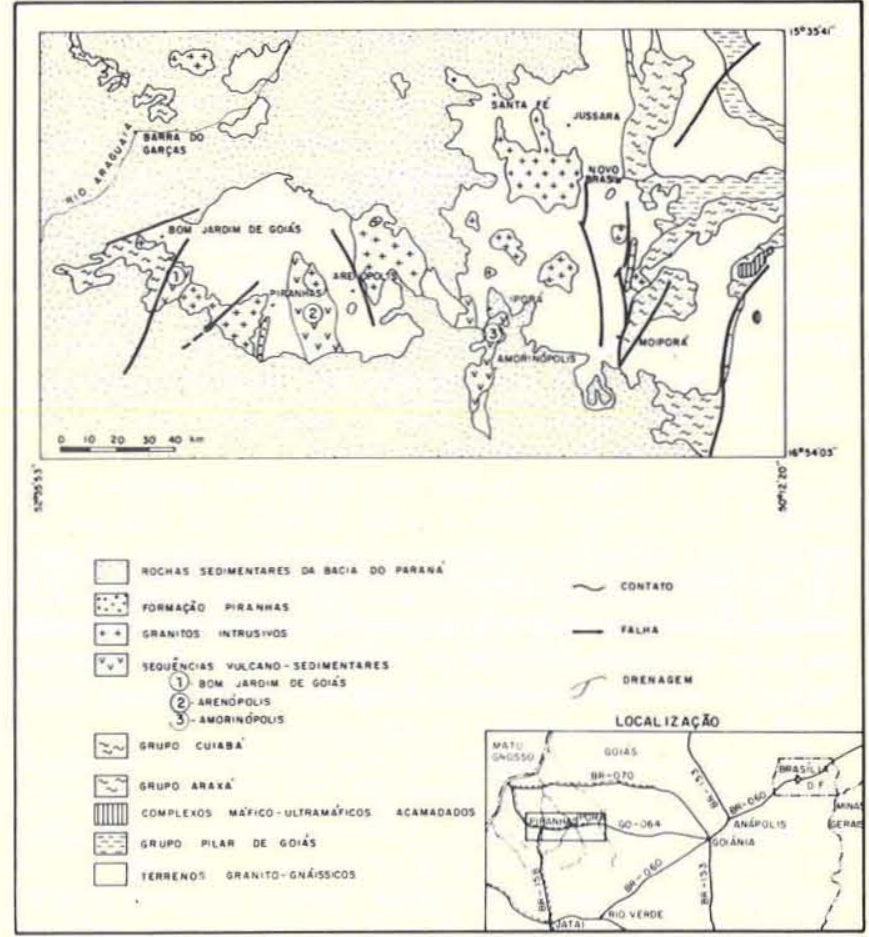

Figura 1 - Mapa geológico regional (modificado de Ianhez et al. 1983) 
A SEQÜENNCIA VULCANO-SEDIMENTAR DE ARENÓPOLIS As rochas que constituem esta seqüência foram incluídas, em trabalhos da década passada (Pena \& Figueiredo 1972, Faria et al. 1975), no Grupo Araxá. Mais recentemente, Ianhez et al. (1983) e Ianhez et al. (1984) verificaram que a composição litológica da referida sequêencia é diferente da do Grupo Araxá e a compararam a uma estrutura do tipo greenstone belt, conferindo-lhe idade arqueana. Os trabalhos de Pimentel (1985) e Pimentel \& Fuck (1986) mostram, no entanto, que as feições mais características que marcam os terrenos do tipo granito-greenstone estão ausentes na geologia da região de Arenópolis-Piranhas.

De acordo com Pimentel (1985), a seqüência vulcano-sedimentar de Arenópolis é constituída por duas unidades principais, separadas por uma estreita faixa de rochas gnáissicas bandadas, localmente migmatizadas. A porção oeste da seqüência é ocupada pela Unidade Córrego Santo Antônio, a qual é composta por micaxistos pelíticos portando granada, cianita, estaurolita e sillimanita, bem como mármores, anfibolitos finos (prováveis metabasaltos), quartzitos finos, metacherts piritosos, além de corpos plutônicos máfico-ultramáficos de dimensões variáveis, caracterizados por anfibolitos de granulação grossa (metagabros), metaperidotitos, metapiroxenitos e serpentinitos. A Unidade Córrego da Onça constitui a porção leste da seqüência, sendo formada por três subunidades: a. a máfica, que representa a porção considerada basal do pacote, é composta por anfibolitos e anfibólio xistos (metabasaltos e metandesitos) apresentando freqüentes feições vulcânicas reliquiares, tais como estruturas em almofada e texturas porfiríticas caracterizadas por antigos fenocristais de plagioclásio, hoje saussuritizados; b. a intermediária-félsica; composta de rochas quartzo-feldspáticas de granulação fina, microporfiríticas, de origem piroclástica e vulcânica, mostrando composições dacítica e riolítica; e c. a metassedimentar, na qual dominam metagrauvacas, micaxistos feldspáticos e quartzitos. As paragêneses mostradas pelas rochas dessa unidade revelam que elas foram submetidas a metamorfismo em condições de PT equivalentes às da zona transicional entre as fácies xisto verde e anfibolito. A Unidade Córrego da Onça é intrudida por diversos pequenos corpos plutônicos a subvulcânicos composicionalmente equivalentes às rochas metavulcânicas.

Uma unidade adicional de rochas metavulcânicas e metapiroclásticas de composição riolítica é também individualizada. Essas rochas são petrográfica, estrutural e quimicamente distintas dos metarriolitos pertencentes à subunidade intermediária-félsica e apresentam teores de $\mathrm{K}_{2} \mathrm{O}$ e $\mathrm{Rb}$ consideravelmente mais elevados, motivo pelo qual não foram incluídas na Unidade Córrego da Onça e têm sido interpretadas como representantes das manifestações finais da atividade vulcânica que deu origem à seqüência vulcano-sedimentar (Pimentel \& Fuck 1986).

As feições estruturais observadas permitiram a individualização de quatro fases de deformação afetando as rochas da sequêencia vulcano-sedimentar de Arenópolis. A primeira gerou uma xistosidade $S_{1}$, de modo geral, paralela ao acamamento original das rochas, o que sugere dobramentos isoclinais e transposição do acamamento durante essa fase. A identificação dessa xistosidade tanto no campo como em lâmina delgada é dificultada pela forte transposição imposta pela segunda fase. Esta é responsável pelas estruturas mais comumente observadas no terreno, representadas por dobras similares, apertadas, levemente assimétricas com planos axiais subverticais. A xistosidade de plano axial $S_{2}$ varia entre NS e N30W e mostra mergulhos subverticais e verticais impedindo, em conseqüência, a caracterização da vergência tectônica. A terceira fase originou crenulações com eixos próximos de NS. A última fase é caracterizada por dobramentos abertos, suaves, ortogonais aos eixos representativos das fases anteriores.

A presença abundante de rochas metavulcânicas máficas, intermediárias e félsicas, associadas a metagrauvacas; a elevada freqüência de texturas piroclásticas atestando a grande importância de atividade vulcânica explosiva, e a presença de pequenos corpos plutônicos/subvulcânicos composicionalmente semelhantes às metavulcânicas configuram para a Unidade Córrego da Onça um quadro geológico com muitas das características dos modernos arcos magmáticos (Pimentel 1985, Pimentel \& Fuck 1986). Feições geológicas similares - em termos de composição petrográfica e química, deformação e grau metamórfico foram verificadas na seqüência vulcano-sedimentar de Bom Jardim de Goiás, igualmente comparada a arcos vulcânicos modernos (Seer 1985, Seer \& Nilson 1986).

Os dados geocronológicos referentes a rochas graníticas da região (Pimentel et al. 1985), bem como a constatação de que as rochas vulcânicas de Bom Jardim de Goiás sofreram a mesma evolução metamórfica e deformativa impressa nos metassedimentos do Grupo Cuiabá (Seer 1985, Seer \& Nilson 1986), levaram à sugestão de que a evolução das sequeências vulcano-sedimentares do sudoeste de Goiás tenha acontecido durante o Proterozóico Superior, em um ambiente tectônico de convergência de placas litosféricas (Pimentel \& Fuck 1986). As relações de campo bem como os dados petrográficos, geoquímicos e isotópicos disponíveis para as rochas graníticas sugerem igualmente que as mesmas têm sua origem ligada ao consumo de litosfera oceânica e posterior choque de massas continentais. As diversas etapas desse processo podem ser, grosso modo, identificadas na evolução do magmatismo granítico regional. Os pequenos corpos gabro-dioríticos intrusivos nas seqüências vulcano-sedimentares podem ser comparados aos granitos do tipo $\mathrm{M}$ da fase intrusiva inicial de um arco de ithas As feições petrográficas, químicas e isotópicas do gränto do Rio Caiapó correspondem às dos granitos tipo I Cordilheirano de margens continentais ativas, enquanto as do granito Serra do Iran se assemelham às dos granitos tipo I Caledoniano, característicos das últimas fases de evolução do cinturão, em regimes pós-colisionais e de soerguimento crustal (Pimentel 1985, Pimentel \& Fuck 1986).

De outra parte, a composição litológica da Unidade Córrego Santo Antônio, que inclui micaxistos pelíticos, mármores, quartzitos, anfibolitos finos e metacherts, além de corpos plutônicos máfico-ultramáficos, lembra as seqüências formadas na posição de arco externo (entre o front vulcânico e a fossa oceânica) comumente referidas como prismas de acreção (Karig \& Sharman 1975). A possibilidade de uma tal comparação foi sugerida em trabalho anterior (Pimentel \& Fuck 1986), de forma que a Unidade Córrego da Onça é interpretada como uma seqüência formada em um arco vulcânico enquanto a Unidade Córrego Santo Antônio representaria uma seqüência de arco externo. A distribuição espacial e o paralelismo das duas unidades sugerem zona de subduç̧ão mergulhando para leste durante a constituição da seqüência vulcano-sedimentar. 


\section{CARACTERISTICAS QUIMICAS GERAIS DAS ROCHAS} METAVULCÂNICAS E METAPLUTÔNICAS As composições químicas das rochas metavulcânicas e metaplutônicas componentes da seqüência vulcano-sedimentar de Arenópolis estão listadas nas tabelas 1, 2 e 3.

Essas rochas mostram caráter subalcalino, o que é confirmado pela presença freqüente de quartzo e hiperstênio na norma CIPW. As rochas metavulcânicas da Unidade Córrego da Onça correspondem quimicamente a basaltos, basaltos andesíticos, andesitos, dacitos, riodacitos e riólitos. As rochas dos pequenos corpos intrusivos associados a essa unidade mostram composição química equivalente às de gabros, dioritos, tonalitos, granodioritos e granitos. Os anfibolitos da Unidade Córrego Santo Antônio possuem composição comparável à de basaltos toleíticos. As rochas metabásicas da Unidade Córrego da Onça exibem também características toleíticas.

A figura 2, na qual os elementos maiores estão plotados contra o índice de diferenciação de Thornton \& Tuttle, mostra que as rochas da Unidade Córrego da Onça apresentam evolução química compatível com uma origem por diferenciação magmática contínua, de basaltos a riólitos. Coerentemente, $\mathrm{TiO}_{2}, \mathrm{Fe}_{2} \mathrm{O}_{3}+\mathrm{FeO}, \mathrm{MgO}$ e $\mathrm{CaO}$ decrescem continuamente em direção aos termos mais ácidos da série, enquanto os álcalis mostram um comportamento oposto, o que é compatível com o fracionamento de minerais ferromagnesianos e de plagioclásio cálcico nos termos iniciais da seqüência de cristalização. A freqüente ocorrência de texturas porfiríticas reliquiares mantidas por antigos fenocristais de plagioclásio nas rochas metavulcânicas básicas de subunidade máfica da Unidade Córrego da Onça demonstra que o processo de fracionamento desse mineral foi importante na evolução química da suíte de rochas vulcânicas. Situação semelhante é observada nos diagramas referentes às rochas metaultramáficas e anfibolíticas da Unidade Córrego Santo Antônio. Nos diagramas $\mathrm{CaO}$ versus ID, $\mathrm{Al}_{2} \mathrm{O}_{3}$ versus ID e $\mathrm{Na}_{2} \mathrm{O}$ versus ID observa-se que ocorre um aumento nas proporções desses elementos quando da passagem das rochas ultramáficas para as máficas, indicando a entrada do plagioclásio na seqüência de cristalização.

As análises químicas das rochas metavulcânicas e dos pequenos corpos intrusivos associados da Unidade Córrego da Onça foram plotadas em um diagrama AFM (Fig. 3a). Os pontos analíticos, apesar da dispersão, delineiam um trend que não apresenta enriquecimento relativo em ferro nos termos intermediários, assemelhando-se mais aos trends observados em suítes calcialcalinas. Já as rochas ultramáficas e máficas da Unidade Córrego Santo Antônio (Fig. 3b) formam um início de trend que, apesar de mostrar uma tendência de enriquecimento em ferro em direção aos termos menos básicos, corta obliquamente o trend toleítico observado para a intrusão acamada de Skaergaard.

A relação entre a geoquímica das rochas e o ambiente geotectônico de origem As análises químicas revelam que parte importante dos anfibolitos e anfibólio xistos da Unidade Córrego da Onça é equivalente a andesitos e andesitos basálticos. A abundância de rochas andesíticas marca caracteristicamente os ambientes de convergência de placas litosféricas (Gill 1981). A associação de rochas metandesíticas com metabasaltos, metadacitos e metarriólitos com pequenos corpos intrusivos composicionalmente equivalentes, que mostram feições locais de cristalização em condições subvulcânicas, bem como a freqüente identifi-

Tabela 1 - Composição química e mineralogia normativa (CIPW) das rochas da Unidade Córrego da Onça e de rochas rioliticas da unidade superior da seqüencia vulcano-sedimentar. Elementos maiores são expressos em porcentagem em peso $e$ os traços, em ppm

\begin{tabular}{|c|c|c|c|c|c|c|c|c|c|c|c|c|c|c|c|c|c|c|c|c|c|c|}
\hline & & \multicolumn{11}{|c|}{ METAULTRAMÁFICAS } & \multicolumn{5}{|c|}{ ANFIBOLITOS GROSSOS } & \multicolumn{5}{|c|}{ ANFIBOLITOS FINOS } \\
\hline & & MP-170 & MP-115 & MP-31A & MP-229 & MP-116A & MP-32 & MP-193B & MP-321 & MP-10 & MP-177 & MP-06B & MP-31C & MP-259C & MP-90A & MP-58 & MP-227 & MP-97 & MP-102B & MP-264 & MP-304A & MP-374 \\
\hline \multirow{12}{*}{\multicolumn{2}{|c|}{$\begin{array}{l}\mathrm{SiO}_{2} \\
\mathrm{TiO}_{2} \\
\mathrm{Al}_{2} \mathrm{O}_{3} \\
\mathrm{Fe}_{2} \mathrm{O}_{3} \\
\mathrm{FeO} \\
\mathrm{MnO} \\
\mathrm{MgO} \\
\mathrm{CaO} \\
\mathrm{Na}_{2} \mathrm{O} \\
\mathrm{K}_{2} \mathrm{O} \\
\mathrm{P}_{2} \mathrm{O}_{5} \\
\mathrm{PF}\end{array}$}} & 39,65 & 40,60 & 40,73 & 42,44 & 42,60 & 43,90 & 44,79 & 44,88 & 45,29 & 45,67 & 46,33 & 49,10 & 49,48 & 49,65 & 49,97 & 50,01 & 49,61 & 49,89 & 50,50 & 51,30 & 51,82 \\
\hline & & 0,39 & 0,34 & 0,40 & 0,44 & 0,58 & 0,49 & 0,61 & 0,53 & 0,34 & 0,53 & 0,34 & 0,79 & 0,82 & 0,85 & 1,28 & 0,66 & 1,91 & 1,78 & 1,14 & 0,53 & 1,79 \\
\hline & & 5,00 & 4,30 & 5,50 & 4,55 & 7,73 & 7,20 & 9,70 & 11,17 & 9,40 & 7,00 & 8,00 & 14,88 & 16,81 & 14,20 & 12,70 & 14,96 & 13,45 & 13,85 & 15,80 & 14,40 & 13,66 \\
\hline & & 7,00 & 8,67 & 7,57 & 8,20 & 7,53 & 3,50 & 6,52 & 7,29 & 6,90 & 7,00 & 4,30 & 4,60 & 2,41 & 5,29 & 4,11 & 3,12 & 3,60 & 2,52 & 3,27 & 4,66 & 3,89 \\
\hline & & 3,57 & 4,50 & 3,80 & 2,83 & 4,50 & 3,00 & 3,40 & 3,55 & 3,89 & 4,23 & 5,18 & 4,61 & 6,55 & 3,00 & 6,05 & 6,22 & 9,97 & 9,97 & 5,79 & 4,52 & 3,64 \\
\hline & & 0,11 & 0,14 & 0,12 & 0,08 & 0,09 & 0,08 & 0,08 & 0,04 & 0,06 & 0,06 & 0,04 & 0,05 & 0,17 & 0,04 & 0,06 & 0,17 & 0,21 & 0,21 & 0,07 & 0,02 & 0,20 \\
\hline & & 31,50 & 29,10 & 28,40 & 27,30 & 23,50 & 23,40 & 21,30 & 20,00 & 18,80 & 23,10 & 21,40 & 7,80 & 6,80 & 10,00 & 10,10 & 9,45 & 7,26 & 6,40 & 7,30 & 7,30 & 6,30 \\
\hline & & 1,47 & 2,26 & 3,23 & 3,60 & 7,00 & 6,44 & 6,50 & 8,91 & 9,80 & 5,80 & 7,40 & 11,90 & 13,30 & 11,70 & 11,27 & 12,53 & 10,62 & 9,80 & 10,68 & 12,00 & 11,03 \\
\hline & & 0,68 & 0,96 & 0,75 & 0,76 & 0,85 & 1,10 & 1,08 & 1,05 & 0,90 & 0,75 & 1,77 & 3,10 & 1,85 & 2,66 & 2,64 & 1,97 & 1,82 & 2,60 & 4,00 & 2,50 & 2,47 \\
\hline & & 0,08 & 0,12 & 0,11 & 0,06 & 0,12 & 0,11 & 0,14 & 0,15 & 0,13 & 0,10 & 0,34 & 1,38 & 0,29 & 1,24 & 0,60 & 0,32 & 0,57 & 0,48 & 0,53 & 0,98 & $<0,10$ \\
\hline & & $<0,10$ & $<0,10$ & $<0,10$ & $<0,10$ & $<0,10$ & $<0,10$ & $<0,10$ & $<0,10$ & $<0,10$ & $<0,10$ & $<0,10$ & $<0,10$ & 0,07 & $<0,10$ & $<0,10$ & 0,04 & 0,14 & 0,26 & $<0,10$ & $<0,10$ & 0,15 \\
\hline & & 10,10 & 8,85 & 9,00 & 9,00 & 5,30 & 5,60 & 3,00 & 1,75 & 6,10 & 5,60 & 4,00 & 1,35 & 1,69 & 1,35 & 1,30 & 1,13 & 0,82 & 0,81 & 0,95 & 1,30 & 0,78 \\
\hline \multicolumn{2}{|c|}{ Total } & \begin{tabular}{|l|}
99,55 \\
\end{tabular} & 99,84 & 99,67 & 99,26 & 99,85 & 99,82 & 97,37 & 99,23 & 99,88 & 99,89 & 99,70 & 99,56 & 100,24 & 99,98 & 100,08 & 100,58 & 99,98 & 99,57 & 99,13 & 99,56 & 100,73 \\
\hline \multirow{11}{*}{\multicolumn{2}{|c|}{$\begin{array}{l}\mathrm{Cu} \\
\mathrm{Pb} \\
\mathrm{Zn} \\
\mathrm{Ni} \\
\mathrm{Cr} \\
\mathrm{V} \\
\mathrm{Rb} \\
\mathrm{Sr} \\
\mathrm{Cs} \\
\mathrm{Y} \\
\mathrm{Zr} \\
\mathrm{Ba} \\
\mathrm{Ba} \\
\end{array}$}} & 35 & 5 & 20 & 25 & 130 & 5 & 20 & 130 & 15 & 75 & 15 & 95 & 158 & 5 & 45 & 136 & 174 & 79 & 150 & 85 & 147 \\
\hline & & 20 & 20 & 25 & 15 & 15 & 20 & 10 & 5 & 20 & 10 & 20 & 15 & 15 & 10 & 10 & 18 & 15 & 15 & 10 & 5 & 2 \\
\hline & & 55 & 25 & 75 & 60 & 25 & 50 & 15 & 10 & 55 & 55 & 35 & 30 & 63 & 20 & 40 & 63 & 100 & 98 & 40 & 15 & 108 \\
\hline & & 1.805 & 1.540 & 1.550 & 1.560 & 1.060 & 1.360 & 635 & 335 & 750 & 1.015 & 325 & 55 & 87 & 70 & 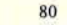 & 175 & 110 & 年 & 0 & 15 & 110 \\
\hline & & 1.040 & 465 & 2.360 & 1.930 & 860 & 2.205 & 455 & 740 & 2.040 & 2.060 & 595 & 195 & 50 & 180 & 170 & 510 & 140 & 180 & 75 & 55 & 180 \\
\hline & & 15 & 30 & 70 & 50 & 100 & 200 & 70 & 70 & 100 & 40 & 200 & 200 & - & 300 & 300 & - & $\therefore$ & - & 200 & 300 & - \\
\hline & & 20 & 20 & - & 15 & 15 & 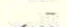 & 10 & - & & 10 & - & - & 59 & 10 & - & 55 & 10 & 8 & 7 & 28 & $<s$ \\
\hline & & $<100$ & $<100$ & $<100$ & $<100$ & $<100$ & $<100$ & $<100$ & $<100$ & $<100$ & $<100$ & $<100$ & 150 & 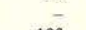 & 150 & 200 & - & 170 & 280 & 240 & 140 & 230 \\
\hline & & $<10$ & $<10$ & $<10$ & $<10$ & $<10$ & $<10$ & 10 & 15 & 15 & 10 & 10 & 10 & 103 & 15 & 20 & 103 & 80 & 114 & $\overline{0}$ & $\overline{20}$ & 11 \\
\hline & & $<10$ & $<10$ & $<10$ & $<10$ & $<10$ & $<10$ & 15 & $<10$ & 15 & 15 & 15 & 20 & - & 20 & 50 & - & - & $\overline{-}$ & $\begin{array}{l}20 \\
20\end{array}$ & $\begin{array}{l}20 \\
20\end{array}$ & $\overline{-}$ \\
\hline & & $<20$ & $<20$ & $<20$ & $<20$ & $<20$ & $<20$ & $<20$ & $<20$ & $<20$ & $<20$ & $<20$ & 100 & - & 100 & 50 & - & 160 & 190 & 110 & 100 & 130 \\
\hline \multirow{11}{*}{ 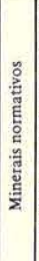 } & Q & 3 & - & - & - & - & - & - & - & 3,14 & - & - & - & 1,10 & - & - & - & 3,60 & 1,66 & - & - & 6,19 \\
\hline & C & 1,23 & 077 & $0 \leq \bar{s}$ & $\overline{-}$ & $\overline{7}$ & $\overline{1}$ & 0. & $0 \overline{-}$ & $\overline{0}$ & $\overline{-}$ & 807 & $\overline{-}$ & 7 & $\overline{3}$ & $35 \overline{5}$ & $18 \overline{9}$ & & & 11 & 70 & - \\
\hline & Or & $\begin{array}{l}0,53 \\
0,35\end{array}$ & $\begin{array}{l}0,77 \\
8,88\end{array}$ & $\begin{array}{l}0,55 \\
6,99\end{array}$ & $\begin{array}{l}0,41 \\
7,02\end{array}$ & $\begin{array}{l}0,77 \\
7,62\end{array}$ & $\begin{array}{l}0,71 \\
9,82\end{array}$ & $\begin{array}{r}0,83 \\
9,39\end{array}$ & $\begin{array}{l}0,89 \\
9,05\end{array}$ & $\begin{array}{l}0,83 \\
8,04\end{array}$ & 0,65 & $\begin{array}{r}2,07 \\
\end{array}$ & 8,16 & $\begin{array}{r}1,71 \\
15\end{array}$ & 7,33 & 3,55 & $\begin{array}{r}1,89 \\
16,67\end{array}$ & $\begin{array}{r}3,37 \\
3,40\end{array}$ & 2,84 & 3,13 & $\begin{array}{r}5,79 \\
\end{array}$ & 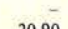 \\
\hline & $\begin{array}{l}A b \\
A n\end{array}$ & $\begin{array}{l}0,35 \\
8,04\end{array}$ & $\begin{array}{l}8,88 \\
7,67\end{array}$ & $\begin{array}{r}6,99 \\
12,10\end{array}$ & $\begin{array}{l}7,02 \\
9,80\end{array}$ & $\begin{array}{r}7,62 \\
17,92\end{array}$ & $\begin{array}{r}9,82 \\
15,18\end{array}$ & $\begin{array}{r}9,39 \\
21,89\end{array}$ & $\begin{array}{r}9,05 \\
25,78\end{array}$ & $\begin{array}{r}8,04 \\
22,53\end{array}$ & $\begin{array}{r}6,68 \\
16,29\end{array}$ & $\begin{array}{l}15,57 \\
15,13\end{array}$ & $\begin{array}{l}18,19 \\
22,61\end{array}$ & $\begin{array}{l}15,65 \\
36,71\end{array}$ & $\begin{array}{l}20,46 \\
23,15\end{array}$ & $\begin{array}{l}22,34 \\
21,03\end{array}$ & $\begin{array}{l}16,67 \\
31,03\end{array}$ & $\begin{array}{l}15,40 \\
26,85\end{array}$ & $\begin{array}{l}22,00 \\
24,70\end{array}$ & $\begin{array}{l}31,57 \\
23,59\end{array}$ & $\begin{array}{l}21,15 \\
25,18\end{array}$ & $\begin{array}{l}20,90 \\
26,19\end{array}$ \\
\hline & $\mathrm{Ne}$ & - & & . & 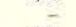 & & & & & & & 15,13 & 4,36 & & 1,11 & & & & 24,10 & 23,59 & 25,18 & 20,19 \\
\hline & $\mathrm{Di}$ & - & 3,61 & 4,00 & 85 & 14,35 & 14,77 & 9,02 & 15,32 & 23,24 & 11,23 & 18,33 & 29,45 & 23,76 & 27,87 & 28,00 & 25,12 & 20,45 & 18,43 & 23.78 & 27,89 & 22,55 \\
\hline & $\mathrm{Hy}$ & 34,00 & 28,49 & 33,10 & 43,43 & 39,00 & 39,88 & 55,72 & 50,81 & 46,49 & 60,38 & 32,62 & & $14 ; 82$ & & 8,39 & 15,93 & 20,64 & 20,53 & - & 12,07 & 14,75 \\
\hline & OI & 47,40 & 48,60 & 40,55 & 29,61 & 22,24 & 20,95 & 5,90 & 4,22 & 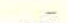 & 6,52 & 18,67 & 10,40 & & 13,39 & 8,38 & 4,23 & & 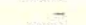 & 8,82 & 1,80 & \\
\hline & Mt & 3,02 & 2,90 & 2,95 & 3,07 & 3,18 & 3,04 & 2,78 & 2,86 & 3,25 & 3,19 & 2,77 & 3,32 & 3,30 & 3,41 & 4,08 & 3,13 & 5,22 & 3,65 & 3,83 & 3,02 & 5,84 \\
\hline & II & 0,82 & 0,70 & 0,81 & 0,91 & 1,16 & 0,99 & 0,70 & 0,85 & 1,23 & 1,16 & 0,66 & 1,50 & 1,50 & 1,61 & 2,48 & 1,25 & 3,63 & 3,38 & 2,17 & 1,10 & 3,40 \\
\hline & Ap & - & - & - & - & - & - & - & - & - & - & - & - & - & - & - & - & 0,33 & 0,60 & - & - & 0,35 \\
\hline
\end{tabular}




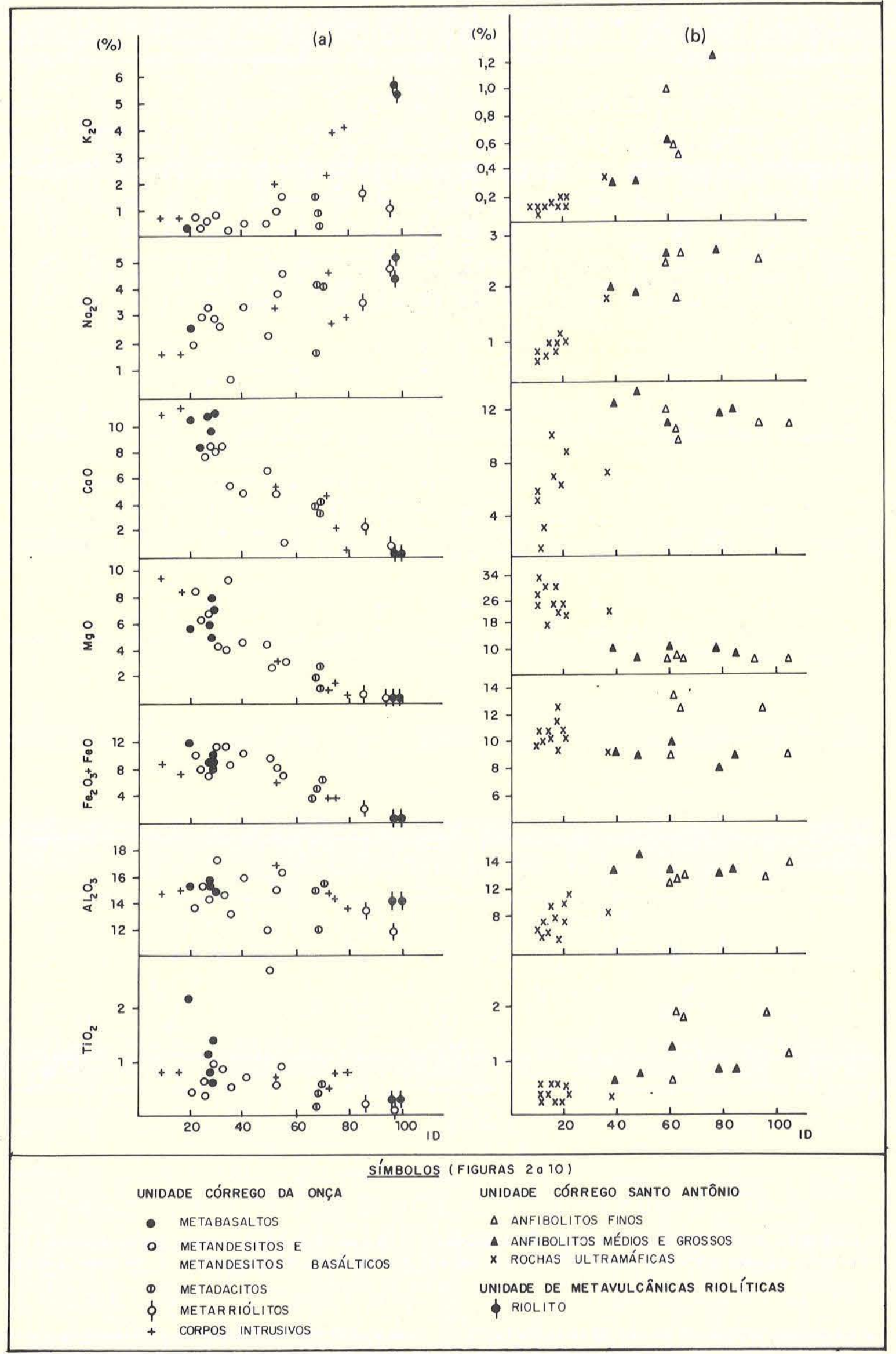

Figura 2 - Diagramas óxidos versus I.D. (índice de diferenciação de Thornton \& Tuttle) para as rochas das unidades Córrego da Onça (a) e Córrego Santo Antônio (b). ID $=Q+O r+A b+N e+K s+L c$ 
Tabela 2 - Composição química e mineralogia normativa (CIPW) das rochas da Unidade Córrego Sto. Antonio e de amostras da unidade de rochas rioliticas tardias $\left(^{*}\right.$ ). Os elementos maiores são expressos em porcentagem em peso e os menores, em ppm

\begin{tabular}{|c|c|c|c|c|c|c|c|c|c|c|c|c|c|c|c|c|c|c|c|c|c|c|c|}
\hline & \multicolumn{6}{|c|}{ METABASALTOS } & \multicolumn{4}{|c|}{ METANDESITOS BASÁLTICOS } & \multicolumn{5}{|c|}{ METANDESITOS } & \multicolumn{4}{|c|}{ METADACITOS } & \multicolumn{4}{|c|}{ MATARRIOLITOS } \\
\hline & MP-332 & MP-47C & MP-240C & MP-69 & MP-64 & MP-146 & MP-49B & MP-404 & MP-130 & MP-150A & MP-60C & MP-39A & MP-364 & MP-339 & MP-33 & MP-242 & MP-235D & MP-26 & MP-336 & MP-334A & MP.246 & MP- $60 \mathrm{~B}^{*}$ & - MP-59B ${ }^{*}$ \\
\hline \multirow{12}{*}{$\begin{array}{l}\mathrm{SiO}_{2} \\
\mathrm{TiO}_{2} \\
\mathrm{Al}_{2} \mathrm{O}_{3} \\
\mathrm{Fe}_{2} \mathrm{O}_{2} \\
\mathrm{FeO} \\
\mathrm{MnO} \\
\mathrm{MgO} \\
\mathrm{CaO} \\
\mathrm{Na}_{2} \mathrm{O} \\
\mathrm{K}_{2} \mathrm{O} \\
\mathrm{P}_{2} \mathrm{O}_{5} \\
\mathrm{PF}\end{array}$} & 49,07 & 50,64 & 50,70 & 50,90 & 51,14 & 52,09 & 52,36 & 53,57 & 54,22 & 54,22 & 55,17 & 57,26 & 57,49 & 58,06 & 60,50 & 61,45 & 66,40 & 66,70 & 67,51 & 73,13 & 77,81 & 73,00 & 73,50 \\
\hline & 2,22 & 1,96 & 1,24 & 1,46 & $\begin{array}{r}0,67 \\
\end{array}$ & 0,81 & 0,92 & 0,95 & 0,38 & 0,64 & 0,85 & 2,76 & 0,78 & 0,52 & 0,64 & 0,92 & 0,54 & 0,54 & 0,20 & 0,04 & 0,14 & 0,15 & 0,16 \\
\hline & 15,18 & 13,67 & 15,80 & 15,00 & 15,00 & 15,18 & 14,64 & 17,33 & 13,72 & 15,45 & 15,40 & 11,87 & 15,91 & 13,11 & 15,15 & 16,61 & 15,37 & 12,10 & 15,10 & 13,53 & 11,86 & 14,30 & 14,40 \\
\hline & 3,57 & 9,33 & 3,59 & 4,74 & 3,51 & 3,69 & 6,48 & 4,06 & 3,43 & 3,65 & 0,59 & 2,96 & 3,41 & 1,80 & 4,56 & 0,75 & 3,69 & 2,37 & $<0,20$ & 0,37 & 1,03 & $<0,10$ & $<0,10$ \\
\hline & 8,46 & 6,02 & 5,50 & 5,25 & 5,84 & 4,66 & 5,07 & 7,45 & 6,56 & 4,50 & 7,95 & 6,91 & 7,08 & 7,11 & 3,96 & 6,53 & 3,19 & 3,62 & 4,90 & 1,76 & 0,54 & 0,45 & 0,52 \\
\hline & 0,03 & 0,20 & 0,05 & 0,07 & 0,08 & 0,09 & 0,24 & 0,17 & 0,19 & 0,08 & 0,02 & 0,22 & 0,19 & 0,23 & 0,13 & 0,18 & 0,14 & 0,08 & 0,09 & 0,08 & 0,02 & 0,08 & 0,05 \\
\hline & 5,75 & 3,22 & 6,20 & 5,20 & 7,00 & 8,00 & 4,25 & 4,72 & 8,45 & 6,60 & 6,50 & 4,75 & 4,89 & 9,49 & 3,00 & 3,15 & 1,40 & 2,90 & 2,04 & 0,62 & 0,04 & $<0,10$ & $<0,10$ \\
\hline & 10,50 & 10,59 & 10,70 & 10,76 & 9,88 & 9,82 & 8,47 & 8,11 & 8,40 & 8,50 & 8,05 & 6,65 & 5,83 & 5,52 & 5,00 & 4,14 & 4,20 & 3,70 & 3,98 & 2,41 & 0,84 & 0,32 & 0,19 \\
\hline & 2,56 & $<0,10$ & 4,15 & 4,55 & 4,76 & 4,20 & 2,69 & 2,86 & 1,89 & 3,25 & 3,05 & 2,26 & 3,42 & 0,73 & 3,88 & 4,62 & 4,10 & 4,24 & 1,60 & 44 & 4,65 & 5,20 & 4,42 \\
\hline & 0,44 & 0,36 & 0,71 & 0,83 & 0,20 & 0,89 & $<0,10$ & 0,74 & 0,74 & 0,53 & 0,32 & 0,40 & 0,50 & 0,20 & 0,93 & 1,53 & 0,44 & 0,78 & 1,53 & 1,68 & 0,91 & 5,30 & 5,67 \\
\hline & 0,25 & 0,13 & $<0,10$ & $<0,10$ & $<0,10$ & $<0,10$ & 0,10 & 0,07 & 0,15 & $<0,10$ & 0,07 & 0,44 & 0,06 & 0,09 & $<0,10$ & 0,07 & $<0,10$ & $<0,10$ & 0,09 & 0,07 & $<0,01$ & $<0,10$ & $<0,10$ \\
\hline & 1,26 & 2,95 & 0,90 & 1,80 & 2,40 & 1,60 & 4,17 & 0,87 & 1,87 & 2,35 & 1,48 & 2,53 & 2,01 & 4,00 & 2,20 & 2,47 & 0,60 & 2,25 & 2,21 & 2,41 & 0,70 & 1,10 & 1,80 \\
\hline Total & 99,26 & 99,07 & 99,54 & 99,96 & 100,24 & 100,08 & 99,85 & 99,69 & 99,16 & 99,69 & 98,93 & 98,89 & 100,72 & 100,86 & 99,97 & 99,42 & 100,07 & 99,18 & 99,24 & 99,70 & 99,42 & 99,89 & 100,20 \\
\hline \multirow{13}{*}{$\begin{array}{l}\mathrm{Cu} \\
\mathrm{Pb} \\
\mathrm{Zn} \\
\mathrm{Ni} \\
\mathrm{Cr} \\
\mathrm{V} \\
\mathrm{Li} \\
\mathrm{Rb} \\
\mathrm{Sr} \\
\mathrm{Cr} \\
\mathrm{Y} \\
\mathrm{Zr} \\
\mathrm{Ba} \\
\end{array}$} & 51 & 34 & 65 & 5 & 10 & 15 & 91 & 119 & 11 & 65 & 105 & 3 & 4 & 92 & 75 & 2 & 120 & 60 & $<1$ & $<1$ & $<1$ & 5 & 5 \\
\hline & 18 & 17 & 5 & 15 & 10 & 1 & 1 & 13 & 23 & 5 & 9 & 15 & $<1$ & $<1$ & 15 & 10 & 5 & & & r & $<3$ & 60 & 35 \\
\hline & 61 & 96 & 25 & 35 & 35 & 40 & 86 & 115 & 81 & 70 & 46 & 100 & 68 & 76 & 85 & 82 & 90 & 85 & 39 & 43 & 67 & 30 & 20 \\
\hline & 74 & 26 & 50 & 35 & 40 & 105 & 43 & 31 & 71 & 90 & 76 & 41 & 21 & 119 & 30 & 52 & 5 & 50 & 9 & 7 & 3 & 5 & 5 \\
\hline & 203 & 10 & 95 & 140 & 30 & 210 & 78 & 15 & 305 & 355 & 210 & 84 & 4 & 570 & 50 & 80 & 10 & 95 & 1 & 1 & 1 & 5 & 5 \\
\hline & . & - & 200 & 300 & 500 & 200 & - & - & - & 200 & - & - & - & - & 300 & - & 300 & 200 & - & - & - & - & - \\
\hline & 3 & 13 & - & 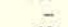 & & & 18 & 8 & 19 & & 5 & 20 & 13 & 18 & - & 34 & - & - & 4 & 17 & 5 & - & - \\
\hline & 10 & 6 & 11 & 10 & $<5$ & 9 & $<$ & 22 & 9 & 15 & $<5$ & 20 & 5 & 23 & 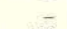 & 48 & 5 & - & 21 & 33 & 36 & - & 750 \\
\hline & 120 & 140 & 140 & 190 & 120 & 250 & 140 & - & 94 & 100 & 200 & 180 & 120 & - & 100 & - & 150 & 200 & 94 & 9 & 69 & - & 18 \\
\hline & 108 & 140 & - & - & - & - & 96 & 29 & 113 & - & 87 & 101 & 16 & 72 & 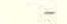 & 15 & - & - & 9 & - & 55 & - & - \\
\hline & - & - & 30 & 50 & 15 & 10 & - & - & - & 15 & - & - & - & - & 20 & - & 20 & 30 & - & - & - & 70 & 70 \\
\hline & - & - & 30 & 100 & 20 & 30 & - & - & - & 20 & - & - & - & - & 20 & - & 50 & 30 & - & - & - & 50 & 70 \\
\hline & 110 & 60 & 30 & 100 & 20 & 100 & 160 & - & 220 & 30 & 52 & 650 & 220 & - & 150 & - & 70 & 150 & 40 & - & 490 & $<20$ & $<20$ \\
\hline \multirow{13}{*}{ 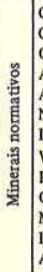 } & 2,72 & 18,12 & - & - & - & - & 9,21 & 6,16 & 6,74 & 5,04 & 5,88 & 21,71 & 13,52 & 22,23 & 15,99 & 17,12 & 26,93 & 25,91 & 36,93 & 39,53 & 45,37 & 21,85 & 25,32 \\
\hline & & & - & 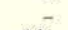 & - & - & , & 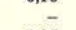 & & 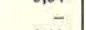 & 0,00 & $2 x, 1$ & 0,73 & 1,85 & & 5,43 & 0,51 & - & 3,75 & 1,82 & 1,70 & - & 0,65 \\
\hline & 2,60 & 2,13 & 4,20 & 4,91 & 1,18 & 5,26 & - & 4,37 & 14,37 & 3,13 & 1,89 & 2,36 & 2,95 & 1,18 & 5,50 & 9,04 & 2,60 & 4,61 & 9,04 & 9,93 & 5,38 & 31,32 & 33,51 \\
\hline & 21,66 & 然 & 30,64 & 30,32 & 33 & 30,30 & 22,76 & 24 , & 1 & 27,50 & 25 & 19 , & 28,94 & 6,18 & 32,83 & 32,09 & 34,6 & 35,88 & 13,54 & 29,11 & 39,35 & 44,00 & 37,40 \\
\hline & 28,63 & 36,24 & 22,39 & 18,06 & 18,97 & 19,94 & 27,87 & 32,27 & 26,77 & 26,00 & 27,39 & 21,06 & 24,60 & 28,86 & 21,18 & $\begin{array}{r}5,24 \\
\end{array}$ & 20,84 & 11,68 & 19,27 & 11,54 & 4,17 & 0,03 & 0,04 \\
\hline & & & 2,42 & 4,43 & 3,57 & 2,79 & & & & & & & - & - & & - & - & $\bar{x}$ & - & - & - & 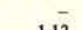 & - \\
\hline & 17,92 & 13,16 & 24,81 & 28,76 & 24,43 & 23,15 & 11,44 & 6,20 & 11,42 & 13,08 & 9,99 & 7,57 & - & - & 3,02 & - & - & 5,46 & - & - & - & 1,12 & - \\
\hline & & & - & - & - & - & & & & & - & - & $=$ & - & - & - & - & - & - & - & - & 0,18 & - \\
\hline & 14,55 & 17,46 & - & - & - & - & 17,82 & 17,78 & 28,25 & 18,19 & 24,84 & 14,26 & 21,51 & 34,77 & 14,70 & 18,03 & 9,75 & 9,67 & 13,92 & 4,29 & 0,21 & - & 0,80 \\
\hline & . & 年 & 7,76 & 4,94 & 11,43 & 11,93 & & - & & 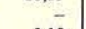 & & 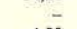 & 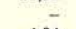 & - & 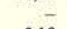 & 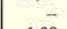 & - & - & - & - & 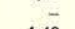 & - & - \\
\hline & 5,18 & 5,02 & 3,97 & 4, & 3,15 & 3, & 3,5 & 5,8 & 2 , & 3 & 0,86 & 4, & 4,94 & 2,61 & 3, & $1, \mathrm{C}$ & 2,96 & 2,83 & - & 0,54 & 1,49 & - & - \\
\hline & 4,22 & 3,72 & 2,36 & 2,77 & 1,27 & 1,54 & 1,75 & 1, & 0,72 & 1,22 & 0,66 & 5,2 & 1,39 & 0,99 & 1,22 & 1,7 & 1,03 & 0,85 & 0,38 & 0,08 & 0,27 & 0,28 & 0,30 \\
\hline & 0,58 & 0,30 & - & - & - & - & 0,16 & 0,16 & 0,35 & - & 0,16 & 1,02 & 0,14 & 0,21 & - & 0,16 & - & - & 0,19 & 0,16 & - & - & - \\
\hline
\end{tabular}

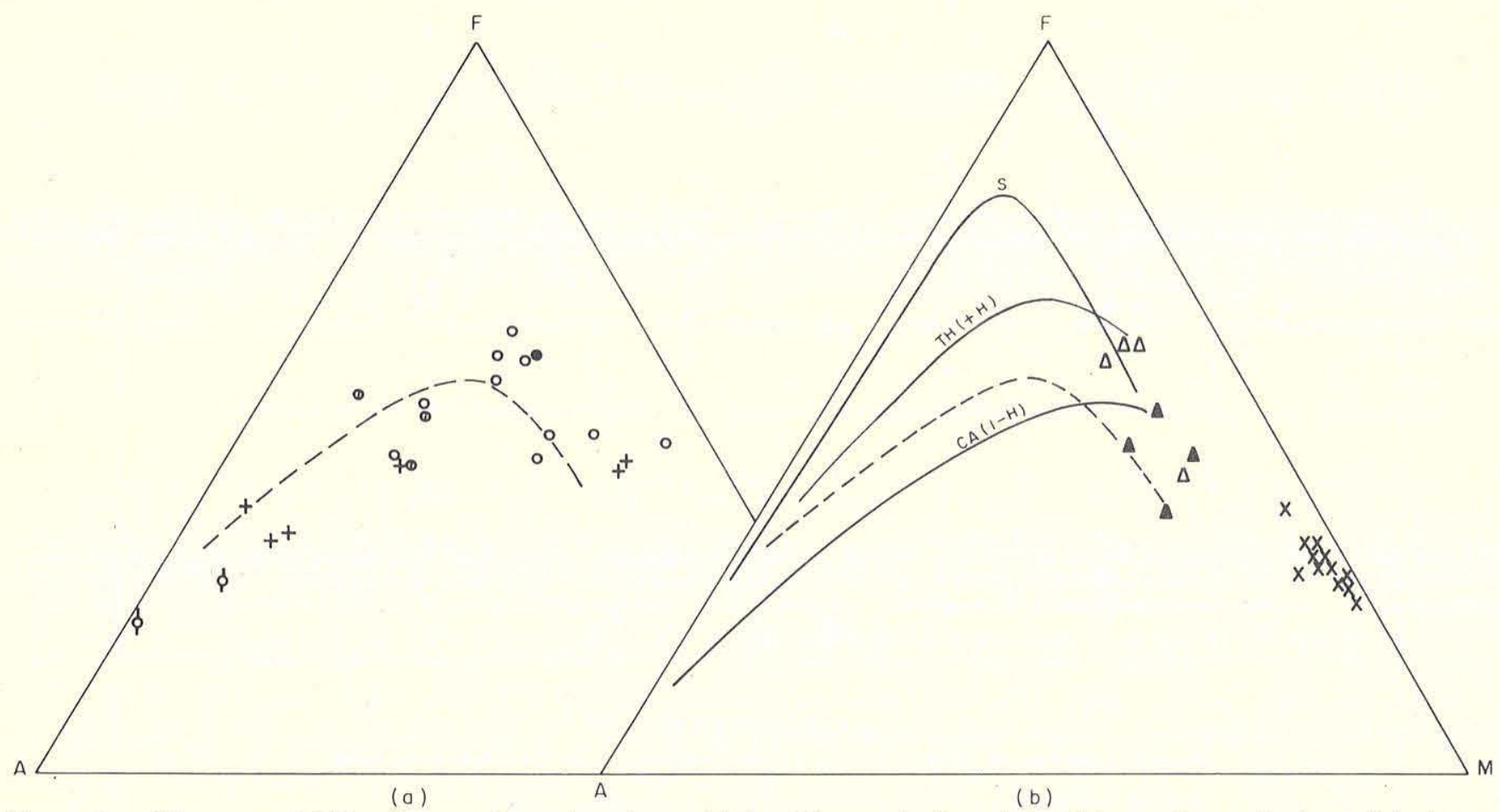

Figura 3 - Diagramas AFM referentes às rochas das unidades Córrego da Onça (a) e Córrego Santo Antônio (b). A linha divisória entre os campos das séries toleiticas (TH) e calcialcalina (CA) è de Irvine \& Baragar (1971). Símbolos como na figura 2

cação de texturas piroclásticas em rochas da Unidade Córrego da Onça, sugere também um ambiente semelhante aos arcos magmáticos modernos. Seer (1985) propôs o mesmo tipo de ambiente para explicar a origem e a evolução da seqüência vulcano-sedimentar de Bom Jardim de Goiás.
Muitos trabalhos têm procurado relacionar a composição química de elementos maiores e traços das rochas ígneas com o ambiente geotectônico por meio de diagramas discriminantes. Esses diagramas têm sido construídos com análises de rochas não alteradas, de idade fanerozóica, e sua 
Tabela 3 - Composição química e mineralogia normativa (CIPW) das rochas dos pequenos corpos intrusivos na Unidade Córrego da Onça. Os elementos maiores estão expressos em porcentagem de peso e os menores, em ppm

\begin{tabular}{|c|c|c|c|c|c|c|c|}
\hline & \multicolumn{2}{|c|}{ METAGABROS } & \multirow{2}{*}{$\begin{array}{c}\text { META- } \\
\text { DIO- } \\
\text { RITO }\end{array}$} & \multicolumn{2}{|c|}{$\begin{array}{l}\text { METAGRANO- } \\
\text { DIORITOS }\end{array}$} & \multirow{2}{*}{\begin{tabular}{|c}
$\begin{array}{c}\text { META- } \\
\text { GRA- } \\
\text { NITO }\end{array}$ \\
MP-24
\end{tabular}} \\
\hline & & MP-120 & MP-187 & & MP-28A & MP-119 & \\
\hline \multirow{12}{*}{\multicolumn{2}{|c|}{$\begin{array}{l}\mathrm{SiO}_{2} \\
\mathrm{TiO}_{2} \\
\mathrm{Al}_{2} \mathrm{O}_{3} \\
\mathrm{Fe}_{2} \mathrm{O}_{3} \\
\mathrm{FeO} \\
\mathrm{MnO} \\
\mathrm{MgO} \\
\mathrm{CaO} \\
\mathrm{Na}_{2} \mathrm{O} \\
\mathrm{K}_{2} \mathrm{O} \\
\mathrm{P}_{2} \mathrm{O}_{5} \\
\mathrm{PF}\end{array}$}} & 49,82 & 53,05 & 58,89 & 65,53 & 57,41 & 70,10 \\
\hline & & 0,86 & 0,86 & 0,72 & 0,53 & 0,79 & 0,86 \\
\hline & & 14,84 & 15,15 & 16,88 & 14,80 & 14,53 & 13,89 \\
\hline & & 1,41 & 0,10 & 1,62 & 0,55 & 0,62 & 0,11 \\
\hline & & 7,43 & 7,47 & 4,57 & 3,41 & 3,49 & 4,27 \\
\hline & & 0,12 & 0,12 & 0,13 & 0,06 & 0,09 & 0,06 \\
\hline & & 9,45 & 8,38 & 2,96 & 1,30 & 1,48 & 0,66 \\
\hline & & 10,78 & 11,26 & 5,29 & 4,75 & 2,35 & 0,44 \\
\hline & & 1,56 & 1,58 & 3,34 & 4,56 & 2,72 & 2,90 \\
\hline & & 0,68 & 0,68 & 1,97 & 2,30 & 3,96 & 4,06 \\
\hline & & 0,10 & 0,14 & - & - & 0,13 & - \\
\hline & & 2,14 & 0,74 & 3,50 & 1,60 & 2,09 & 3,00 \\
\hline \multicolumn{2}{|c|}{ TOTAL } & 99,19 & 99,53 & 99,87 & 99,39 & 99,69 & 100,35 \\
\hline \multirow{9}{*}{\multicolumn{2}{|c|}{$\begin{array}{l}\mathrm{Cu} \\
\mathrm{Pb} \\
\mathrm{Zn} \\
\mathrm{Ni} \\
\mathrm{Cr} \\
\mathrm{Li} \\
\mathrm{Rb} \\
\mathrm{Sr} \\
\mathrm{Cs}\end{array}$}} & 65 & 73 & - & 5 & 7 & 25 \\
\hline & & 13 & 15 & - & 20 & 17 & 15 \\
\hline & & 65 & 65 & - & 50 & 62 & 55 \\
\hline & & 110 & 127 & - & 15 & 30 & 25 \\
\hline & & 380 & 385 & - & 25 & 26 & 45 \\
\hline & & 18 & 10 & - & - & 27 & - \\
\hline & & 67 & 25 & - & - & 113 & - \\
\hline & & - & 140 & - & 500 & - & 100 \\
\hline & & 34 & 30 & - & - & 10 & - \\
\hline \multirow{10}{*}{ 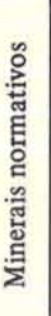 } & & 0,70 & 4,25 & 13,61 & 18,04 & 27,35 & 32,83 \\
\hline & C & - & - & - & - & 1,78 & 3,93 \\
\hline & Or & 4,03 & 4,02 & 11,64 & 13,59 & 23,40 & 23,99 \\
\hline & $A b$ & 13,20 & 13,37 & 28,26 & 38,59 & 23,02 & 24,54 \\
\hline & An & 31,48 & 32,24 & 25,25 & 13,12 & 10,79 & 2,18 \\
\hline & $\mathrm{Di}$ & 17,31 & 18,55 & 0,82 & 8,77 & - & - \\
\hline & Hy & 26,44 & 24,27 & 13,08 & 3,87 & 8,45 & 8,09 \\
\hline & $\mathrm{Mt}$ & 2,04 & 0,14 & 2,35 & 0,80 & 0,90 & 0,16 \\
\hline & II & 1,63 & 1,63 & 1,37 & 1,01 & 1,50 & 1,63 \\
\hline & Ap & 0,23 & 0,33 & - & - & 0,30 & - \\
\hline
\end{tabular}

utilização para as rochas metamórficas tem sido testada e amplamente discutida. Sabe-se que processos pós-magmáticos, tais como o metamorfismo, a alteração hidrotermal e o intemperismo de fundo oceânico, podem ocasionar modificações nas características geoquímicas originais das rochas. Algumas modificações foram verificadas em certas amostras analisadas. $\mathrm{O}$ elevado teor em ferro da amostra MP-47C e os baixos valores em álcalis das amostras MP-47C, MP-339 e MP-246 podem estar indicando a incidência de alteração hidrotermal sobre essas rochas. O diagrama $\mathrm{Na}_{2} \mathrm{O} / \mathrm{K}_{2} \mathrm{O}$ versus $\mathrm{Na}_{2} \mathrm{O}+\mathrm{K}_{2} \mathrm{O}$ de Miyashiro (1975a) da figura 4 mostra que as rochas metavulcânicas de Arenópolis caem no campo das rochas não alteradas por processos pós-magmáticos, sugerindo não terem sido as modificações tão intensas a ponto de alterar substancialmente as características geoquímicas gerais das rochas estudadas. Nesse mesmo diagrama verifica-se que a grande maioria das amostras analisadas mostra teores em álcalis similares aos de rochas vulcânicas de arcos de ilhas cenozóicos. A mesma conclusão pode ser alcançada pelo diagrama Ba versus $\mathrm{FeO} * / \mathrm{MgO}$ de Miyashiro (1975b) mostrado na figura 5 . Os teores em $\mathrm{Ba}$ dessas rochas são mais compatíveis com um ambiente do tipo arco de ilhas que com um ambiente de margem continental ativa.

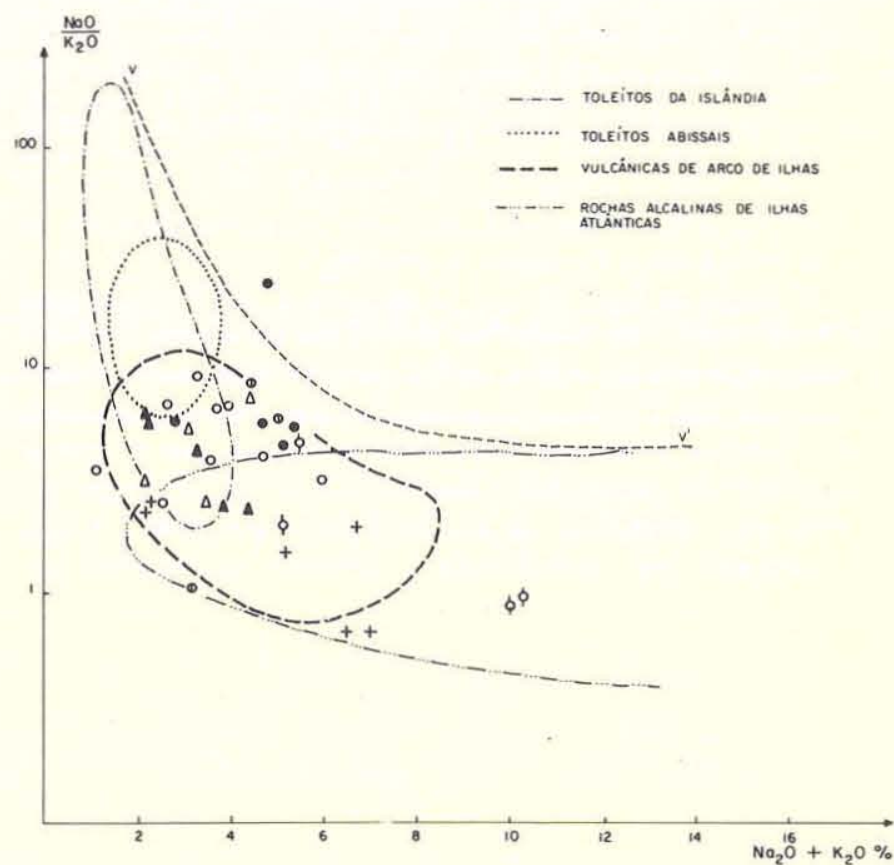

Figura 4 - Diagrama de Miyashiro (1975a) separando os campos de rochas vulcânicas cenozóicas alteradas por qualquer processo pós-igneo (acima da linha VV') e rochas não alteradas (abaixo da linha VV'). Simbolos como na figura 2

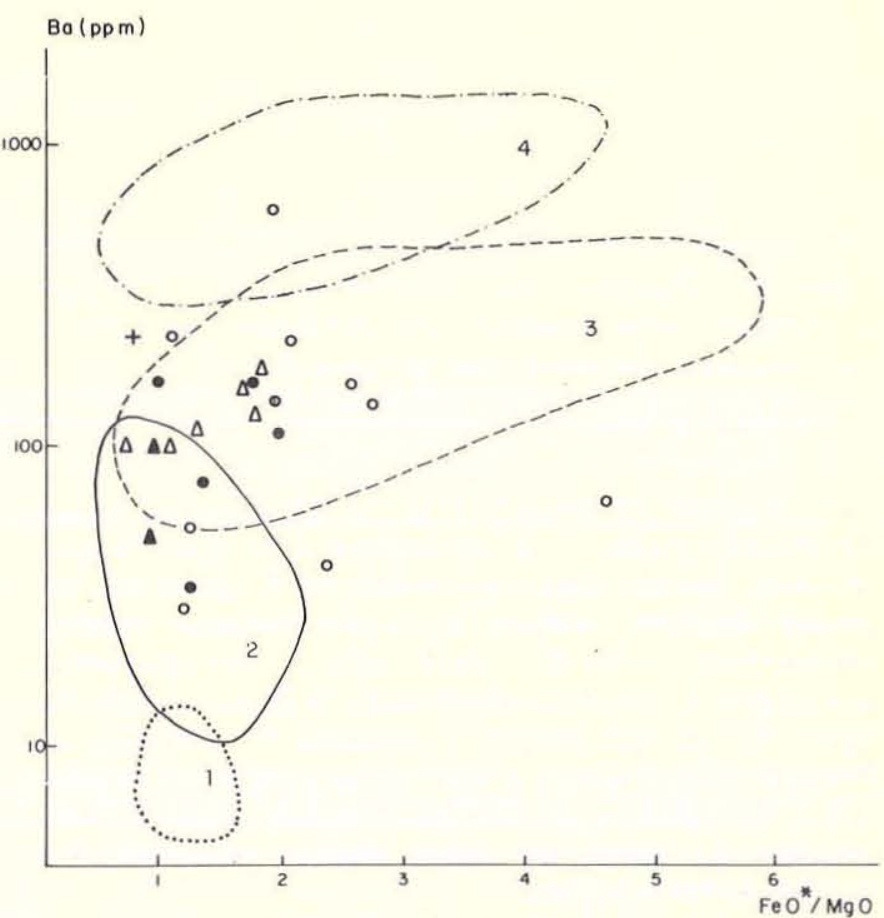

Figura 5 - Diagrama $\mathrm{Ba}$ versus $\mathrm{FeO}^{*} / \mathrm{MgO}$ de Miyashiro (1975b) discriminando os campos de rochas toleiticas de fundo oceânico (campos 1 e 2), de rochas vulcânicas de arco de ilha (campo 3) e de rochas vulcânicas de margem continental ativa (campo 4). A maioria das amostras da Seqüência Vulcano-sedimentar de Arenópolis está plotada no campo das rochas vulcânicas de arco. Símbolos como na figura 2

A maior parte dos trabalhos que procuram relacionar a composição química das rochas com o ambiente geotectônico tem-se utilizado de rochas de composição basáltica. Pearce (1976) reconhece seis grupos de magmas basálticos, 
classificados de acordo com o ambiente geotectônico: basaltos de fundo oceânico; toleítos de arco de ilhas ou toleítos de baixo potássio; basaltos calcialcalinos; basaltos shoshoníticos; basaltos de ilhas oceânicas; e basaltos continentais. Alguns diagramas discriminantes foram utilizados de forma a se compararem as rochas metabásicas estudadas com esses grupos de rochas basálticas.

$\mathrm{O}$ diagrama $\mathrm{K}_{2} \mathrm{O}-\mathrm{TiO}_{2}-\mathrm{P}_{2} \mathrm{O}_{5}$ (Pearce et al. 1975) da figura 6 foi utilizado com o objetivo de verificar a natureza oceânica ou continental das rochas metabásicas de Arenópolis. Observa-se que, das 12 amostras analisadas, oito plotam no campo dos basaltos oceânicos. Os pontos analíticos, até os que se localizam no campo dos basaltos continentais, formam um trend em direção ao vértice do $\mathrm{K}_{2} \mathrm{O}$, o que pode ter sido ocasionado por modificações químicas pós-magmáticas.

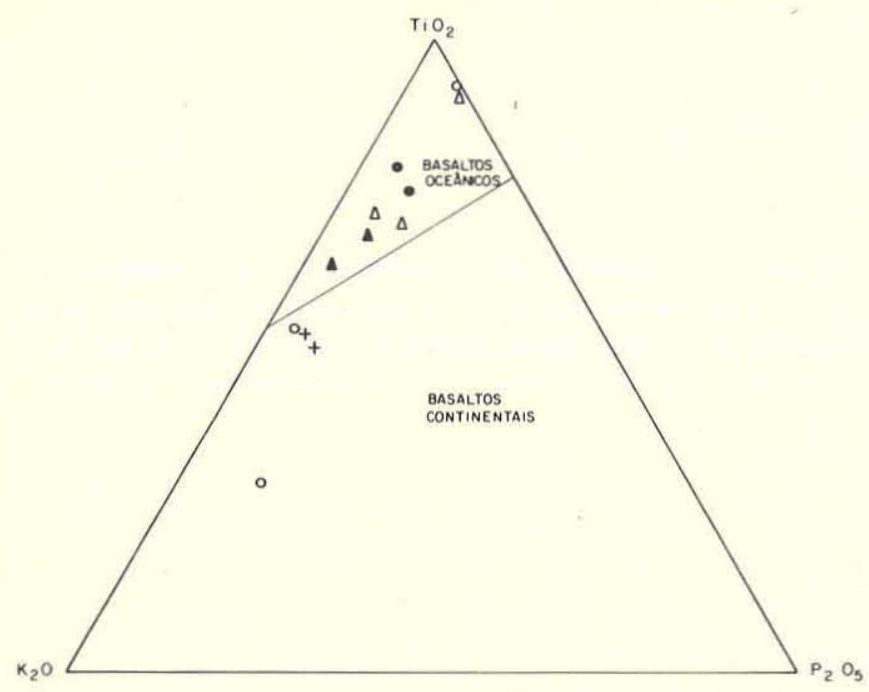

Figura 6 - Diagrama usado por Pearce et al. (1975) para discriminar entre basaltos de ambientes oceânicos $e$ não-oceânicos. Simbolos como na figura 2

$\mathrm{O}$ diagrama $\mathrm{Cr}$ versus $\mathrm{Y}$ (Fig. 7) revela que as rochas metabásicas analisadas se assemelham a basaltos de arco de ilhas. Basaltos desse tipo podem ser divididos em três grupos distintos: toleítos de baixo potássio, basaltos calcialcalinos e basaltos shoshoníticos, correspondentes aos grupos 2, 3 e 4 da classificação de Pearce (1976). Na figura 8 está representado o diagrama $F_{1}$ versus $F_{2}$ de Pearce (1976), o qual revela ser a maior parte dos metabasaltos da seqüência de Arenópolis plotada dentro ou bem próximo do campo que reúne basaltos calcialcalinos e toleítos de baixo potássio.

Os diagramas de Pearce \& Cann (1973) das figuras 9 e 10 mostram que, em relação aos elementos $\mathrm{Zr}$, Ti e $\mathrm{Sr}$, essas rochas correspondem a toleítos de baixo potássio apresentando teores relativamente baixos de $\mathrm{Zr}$.

Análise de elementos terras-raras foi realizada em duas amostras de metabasaltos (MP-64 e MP-146) da Unidade Córrego da Onça. Os conteúdos desses elementos nas rochas analisadas revelaram um padrão pouco fracionado, sem anomalia de $\mathrm{Eu}$, sendo observado um leve enriquecimento em terras-raras leves, especialmente na amostra MP-146 $(\mathrm{La} / \mathrm{Yb}=4,7)$ (Fig. 11). A razão $\mathrm{La} / \mathrm{Yb}$ para a amostra MP-64 é de 2,3. De acordo com Jakes \& Gill (1970), os toleítos de arcos de ilha modernos, em geral, mostram

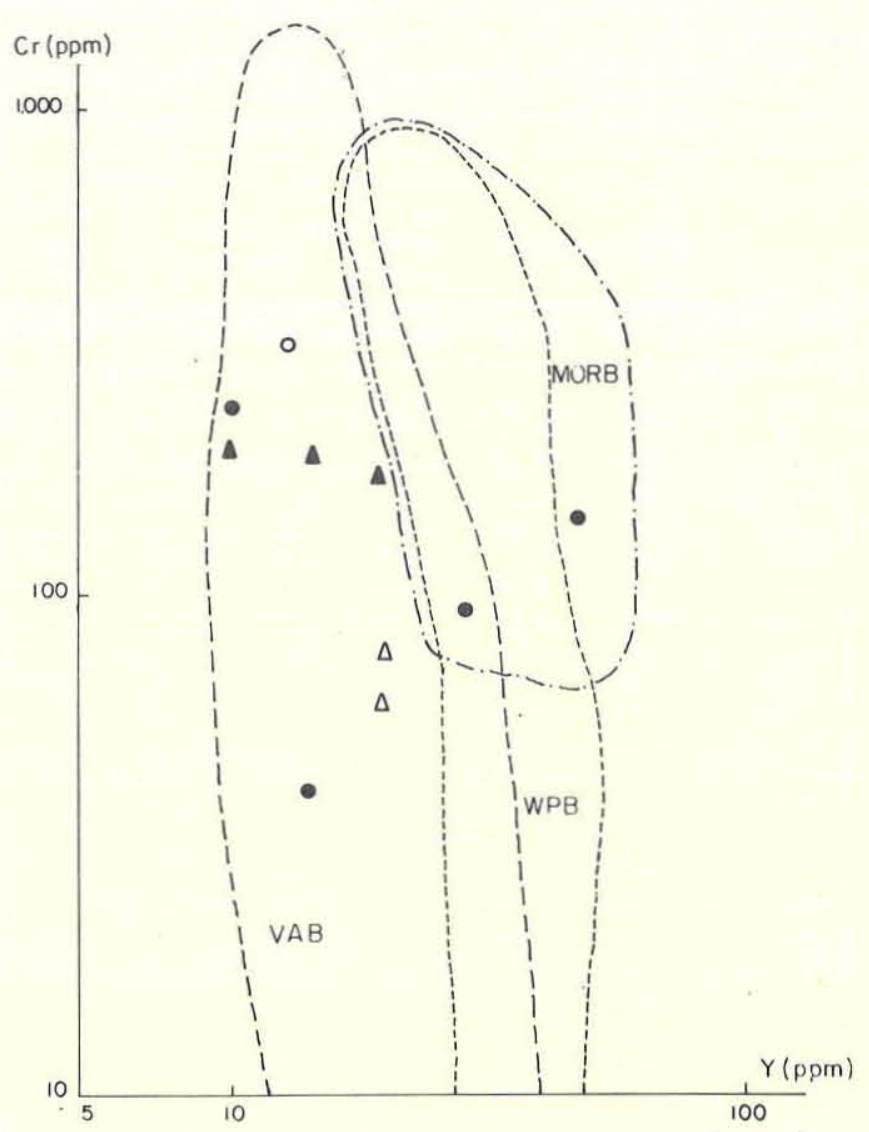

Figura 7 - Diagrama $C r$ versus $Y$ de Pearce et al. (1981) mostrando os campos dos basaltos de arco vulcânico (VAB), basaltos de cadeia mesoceânica (MORB) e basaltos intraplacas (WPB). As rochas metabásicas da seqüência vulcano-sedimentar caem de preferência no campo dos basaltos de arco. Simbolos como na figura 2

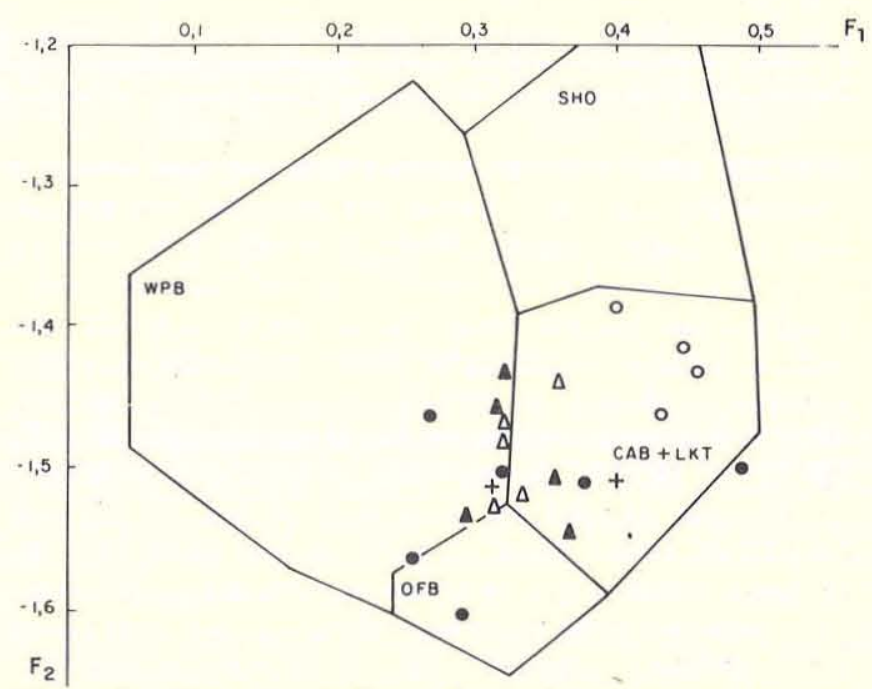

Figura 8 - Diagrama de Pearce (1976) distinguindo basaltos intraplacas (WPB), shoshonitos (SHO), basaltos de arco de ilha [incluindo toleitos de baixo potássio (LKT) e basaltos calcialcalinos $(C A B)$ ] e basaltos de fundo oceânico (OFB). Simbolos como na figura 2. $\mathbf{F}_{1}=0,0088 \mathrm{SiO}_{2}-$ $0,0774 \mathrm{TiO}_{2}+0,0102 \mathrm{Al}_{2} \mathrm{O}_{3}+0,0066 \mathrm{FeO}-0,0017$ $\mathrm{MgO}-0,0143 \mathrm{CaO}-0,0155 \mathrm{Na}_{2} \mathrm{O}-0,0007 \mathrm{~K}_{2} \mathrm{O}$; $\mathbf{F}_{2}=0,013 \mathrm{SiO}_{2}-0,0185 \mathrm{TiO}_{2}-0,0129 \mathrm{Al}_{2} \mathrm{O}_{3}-$ $0,0134 \mathrm{FeO}-0,03 \mathrm{MgO}-0,0204 \mathrm{CaO}-0,0481 \mathrm{Na}_{2} \mathrm{O}+$ $0,0715 \mathrm{~K}_{2} \mathrm{O}$ 


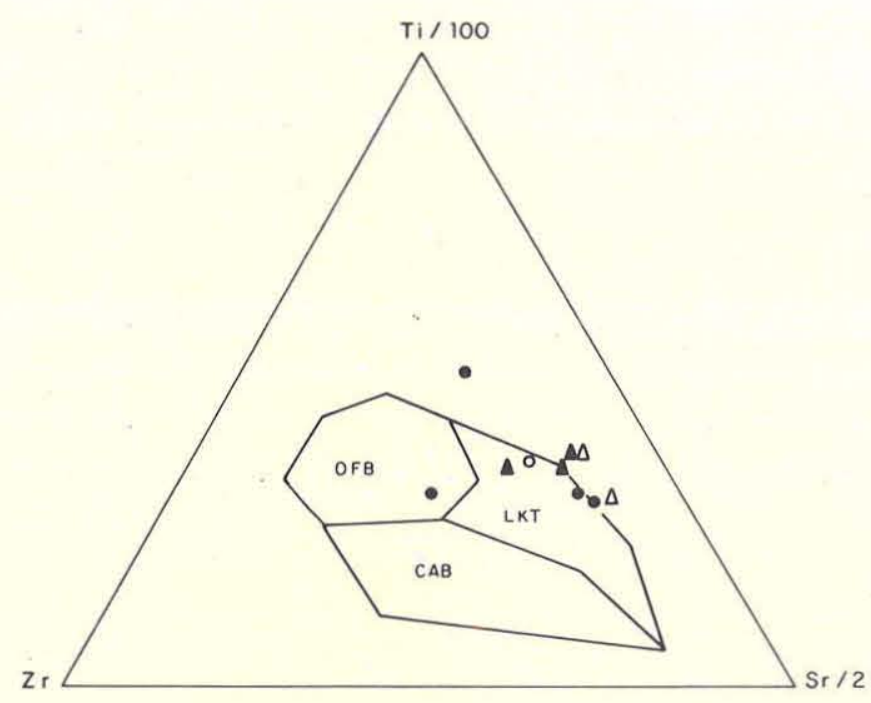

Figura 9 - Diagrama $\mathrm{Zr}-\mathrm{Ti} / 100-\mathrm{Sr} / 2$ de Pearce \& Cann (1973) distinguindo os campos dos basaltos de fundo oceânico (OFB), toleitos de baixo potássio (LKT) e basaltos calcialcalinos (CAB). As rochas metabásicas da seqüência vulcano-sedimentar de Arenópolis assemelham-se aos toleitos de baixo potássio. Símbolos como na figura 2

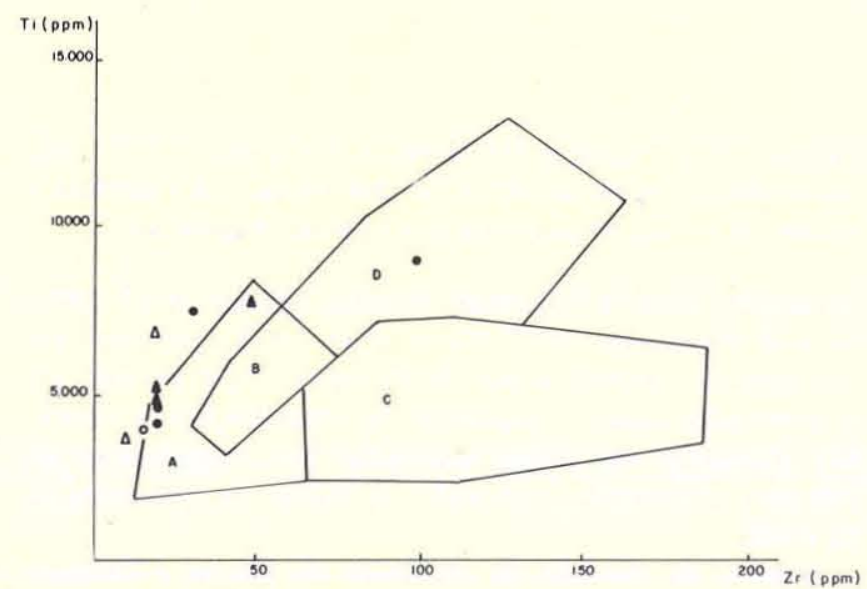

Figura 10 - Diagrama Ti versus $Z r$ de Pearce \& Cann (1973) apontando os campos dos basaltos de fundo oceânico (B e D), toleitos de baixo potássio (A $e$ B) e basaltos calcialcalinos ( $\mathbf{C}$ e $\mathbf{B}$ ). Os baixos teores de $\mathrm{Zr}$ das amostras metabásicas analisadas são característicos dos toleitos de baixo potássio. Símbolos como na figura 2

baixo conteúdo total de terras-raras e um pequeno fracionamento entre as terras-raras leves e as pesadas, sendo caracterizados por baixas razões $\mathrm{La} / \mathrm{Yb}$ (geralmente menores que 3,0 ). As razões $\mathrm{La} / \mathrm{Yb}$ para basaltos calcialcalinos mostram uma ampla faixa de variação, com valores entre 5,0 e 20,0 , sendo que a maior parte se agrupa no intervalo entre 6,0 e 8,0 . De acordo com esses critérios, o metabasalto MP-64 pode ser comparado aos toleítos de arco de ilha modernos enquanto o padrão apresentado pela amostra MP-146 pode ser considerado transicional entre os de basaltos toleíticos de arco e os calcialcalinos, devido ao maior fracionamento verificado entre as terras-raras leves e as pesadas.

Assim, as características geoquímicas gerais das rochas da seqüência vulcano-sedimentar de Arenópolis são compa-

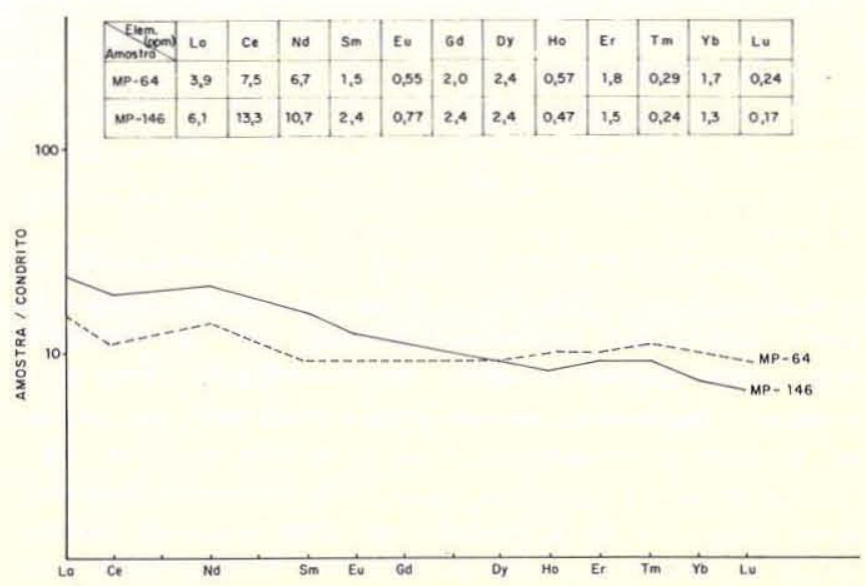

Figura 11 - Padrões de elementos terras-raras para duas amostras de rochas metabasálticas da Unidade Córrego da Onça. Os dadọs utilizados para a normalização são de Evensen et al. (1978)

ráveis às das rochas vulcânicas de arcos magmáticos modernos, sendo que os anfibolitos e anfibólio xistos, tanto da Unidade Córrego da Onça como da Unidade Córrego Santo Antônio, mostram similaridades com os toleítos de baixo potássio, que, de acordo com Pearce (1976) e Kuno (1968), são extravasados nos estágios precoces de desenvolvimento de um arco de ilhas.

\section{CONSIDERAÇÕES SOBRE O AMBIENTE GEOTECTÓ.}

NICO Evolução geotectônica As características de campo, petrográficas, geoquímicas e isotópicas apresentadas pelas rochas da seqüência vulcano-sedimentar e pelos terrenos graníticos adjacentes (Pimentel 1985) permitem uma interpretação a respeito do ambiente geotectônico no qual elas ter-se-iam originado e evoluído, bem como a respeito das implicações de caráter regional provenientes dessa interpretação.

Os dados de campo, petrográficos e geoquímicos sugerem que as rochas metavulcânicas e metassedimentares da região de Arenópolis-Piranhas têm sua formação e evolução relacionadas a um ambiente semelhante aos de arcos magmáticos modernos, em zonas de convergência de placas litosféricas. As principais evidências são as seguintes: 1. Presença de uma seqüência composta dominantemente por rochas metavulcânicas e metapiroclásticas (Unidade Córrego da Onça) de composição básica, intermediária e ácida, entre as quais se destaca a presença marcante de rochas de composição andesítica.

2. Presença de pequenos corpos intrusivos com feições subvulcânicas locais na Unidade Córrego da Onça, compostos de rochas composicionalmente semelhantes às metavulcânicas.

3. O caráter calcialcalino do magmatismo que deu origem às rochas da subunidade intermediária-félsica da Unidade Córrego da Onça. De acordo com Garcia (1978), erupções calcialcalinas são restritas quase que exclusivamente a arcos vulcânicos.

4. A freqüente identificação de texturas piroclásticas em rochas da seqüência vulcano-sedimentar. Os arcos vulcânicos modernos são caracterizados por uma grande incidência de erupções explosivas.

5. Presença de extensos corpos de rochas graníticas porfiríticas, levemente deformadas (tipo granito do Rio Caiapó), 
exibindo uma larga faixa de variação de tipos petrográficos e filiação calcialcalina.

6. As rochas de composição equivalente às de basaltos e andesitos basálticos mostram características geoquímicas comparáveis às de toleítos de baixo potássio de arcos de ilhas.

As semelhantes existentes entre os conjuntos litológicos que afloram na região de Arenópolis e as seqüências de arcos magmáticos modernos sugerem que os processos que deram origem a ambos são semelhantes. Isto é, a evolução magmática, metamórfica e estrutural das rochas de Arenópolis provavelmente foi governada pelos mecanismos da tectônica de placas. Assim, elas ter-se-iam formado sobre uma zona de subducção, em uma região de convergência de duas massas continentais que terminariam por se chocar e se soldar no final do processo. A julgar pelas idades $\mathrm{Rb}$-Sr obtidas nas rochas graníticas (Pimentel et al. 1985), tais processos teriam operado durante o Proterozóico Superior. Seer (1985), ao comparar a evolução tectono-metamórfica da seqüência vulcano-sedimentar de Bom Jardim de Goiás com a do Grupo Cuiabá, corrobora essa interpretação.

Partindo do pressuposto de que toda orogênese de colisão é precedida de uma orogênese de arco - ou seja, os elementos orogenéticos são gerados em um arco magmático pelo consumo da litosfera oceânica que separa as duas massas -, Dickinson (1981) acredita que os cinturões ígneos e metamórficos pré-cambrianos devem representar uma superposição de elementos orogenéticos de arco e de colisão continental. A geologia da região de Arenópolis-Piranhas apresenta elementos que aparentemente correspondem a toda evolução de um arco magmático, do derrame de lavas toleíticas pobres em potássio e intrusões gabro-dioríticas associadas, ao derrame de rochas riolíticas ricas em $\mathrm{K}_{2} \mathrm{O}$ e $\mathrm{Rb}$, do final da evolução da pilha vulcânica e a intrusão de corpos graníticos pós-tectônicos, potássicos, como os granitos da Serra do Iran e da Serra Negra. Essa evolução pode ser observada no diagrama $\mathrm{Rb}$ versus $\mathrm{Sr}$ da figura 12, o qual se baseia no fato de existir uma correspondência entre os teores de $\mathrm{Rb}$ e $\mathrm{Sr}$ e a espessura e estágio de evolução da crosta sob os arcos magmáticos. Isto é, séries toleíticas de arcos jovens associam-se geralmente a regiões onde a crosta não ultrapassa $20 \mathrm{~km}$ de espessura bem como a zonas de subducção rasas $(<150 \mathrm{~km})$. As séries calcialcalinas ocorrem, geralmente, sobre crosta de espessura intermediária $(20-30 \mathrm{~km})$ e as shoshoníticas desenvolvem-se sobre crosta mais espessa $(>30 \mathrm{~km})$. A distribuição dos pontos analíticos referentes às rochas metavulcânicas da Unidade Córrego da Onça sugere formação em um estágio precoce do desenvolvimento do arco, sobre crosta mais fina, provavelmente em um arco de ilhas ensimático, enquanto que os referentes aos granitos da Serra do Iran e do Rio Caiapó indicam uma situação de maior maturidade do arco, já tendo havido, possivelmente, o desenvolvimento de crosta continental mais espessa. Assim, sugere-se que a evolução geotectônica brasiliana na região sudoeste de Goiás tenha-se dado a partir de arcos ensimáticos imaturos que, por mecanismos de tectônica de placas, agregaram-se e formaram uma massa protocontinental maior. Todo esse processo culminou com o choque e a união das duas massas continentais que se aproximavam, a intrusão de granitos pós-tectônicos do tipo da Serra do Iran e da Serra Negra e o estabelecimento de grabens, nos quais se teriam depositado seqüências de caráter

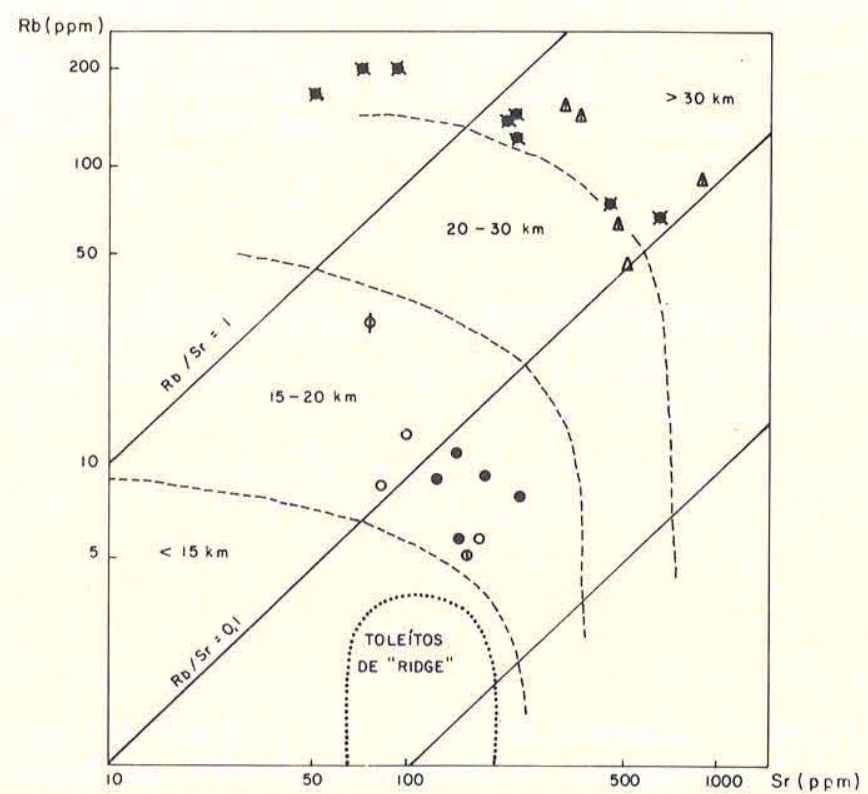

$$
\begin{aligned}
& \text { a granito do rio caIapó } \\
& \text { - GRanito da serra do iran } \\
& \text { UNIDADE córRego DA ONÇa } \\
& \text { - metavulcānicas bás:cas } \\
& \text { - metandesitos } \\
& \text { - metadacito } \\
& \text { Q METARRIólito }
\end{aligned}
$$

Figura 12 - Diagrama $R b$ versus $S r$ de Condie (1973) relacionando os teores de $\mathrm{Rb}$ e $\mathrm{Sr}$ das rochas e a espessura $e$ estágio de evolução da crosta sob os arcos magmáticos

molássico, como a Formação Piranhas (Rosito et al. 1971, Pena \& Figueiredo 1972, Faria et al. 1975), presente em um pequeno gráben a sul de Piranhas e que podem ser interpretadas como o resultado de acumulações continentais formadas em fossas associadas ao soerguimento do cinturão colisional, marcando o início da cratonização da região.

Dentro do modelo da tectônica de placas, a Unidade Córrego Santo Antônio foi interpretada por Pimentel (1985) e Pimentel \& Fuck (1986) como parte de uma sequêencia formada na posição de arco externo, entre o arco vulcânico e a fossa oceânica, na forma de um prisma de acreção. Seqüências semelhantes, constituídas por micaxistos pelíticos, filitos quartzosos, metabasaltos, mármores, metacherts e corpos máfico-ultramáficos, são encontradas em sítios de convergência de placas litosféricas fanerozóicas em diversas partes do mundo, como, por exemplo, nos terrenos paleozóicos do Chile (Gana \& Hervé 1983, Hervé et al. 1984, Thiele \& Hervé 1984). Dessa forma, podem-se aventar duas hipóteses para explicar a origem dos corpos máfico-ultramáficos encontrados na Unidade Córrego Santo Antônio. Uma é a de que eles representem antigos corpos intrusivos diferenciados, formados a partir da injeção de magma basáltico toléítico oriundo dos processos magmáticos que iniciaram a formação do arco. A segunda hipótese é a de que eles representem fragmentos de crosta oceânica obductados e adicionados ao prisma de acreção.

As características químicas das rochas metabásicas desses corpos máfico-ultramáficos não mostram similaridades com as dos basaltos de fundo oceânico modernos. 
As feições geoquímicas de elementos maiores e traços dessas rochas, como se observa nas figuras $4,5,7,8,9$ e 10 , são similares às das rochas metabásicas da Unidade Córrego da Onça, isto é, elas também são geoquimicamente semelhantes a basaltos toleíticos de baixo potássio. Entretanto o critério geoquímico não é definitivo no que concerne à origem desses corpos, já que as rochas metabásicas de diversos corpos ofiolíticos de diferentes cinturões orogenéticos do mundo têm mostrado características químicas diferentes das de basaltos de fundo oceânico, denotando ambientes de arco vulcânico ou de back-arc (Miyashiro 1973, Bakor et al. 1976, Pearce et al. 1981), como é o caso, por exemplo, do ofiólito de Jabal al Wask (Bakor et al. 1976, Frisch \& Al-Shanti 1977), encontrado nos terrenos pan-africanos do NW da Arábia e interpretado, juntamente com outros corpos gabroico-ultramáficos menores como remanescentes de uma antiga bacia de back-arc.

Implicações regionais A identificação de seqüências vulcano-sedimentares típicas de arco magmático - como as de Bom Jardim de Goiás (Seer 1985) e Arenópolis (Pimentel 1985), bem como as de grandes massas plutônicas calcialcalinas, uma das quais mostrando idade brasiliana (granito do Rio Caiapó), a sudoeste de Goiás - indica um importante evento formador de rochas no final do Proterozóico. Seqüências vulcano-sedimentares possivelmente comparáveis às de Bom Jardim e de Arenópolis ocorrem em outras áreas no sudoeste de Goiás, distribuídas em uma faixa de aproximadamente $180 \mathrm{~km}$ de largura, entre as regiões de Bom Jardim e Israelândia. Os sistemas de arcos atuais, de acordo com Gass (1982), são estreitos, raramente excedendo $100-150 \mathrm{~km}$ de largura, desde a fossa até a bacia de back-arc, sendo que a faixa de vulcanismo ativo está usualmente confinada a zonas axiais com larguras menores que $50 \mathrm{~km}$. Portanto a idéia de evolução a partir de um sistema de multiarcos para a região sudoeste de Goiás é plausível. Os arcos magmáticos modernos, entretanto, são geralmente bastante extensos longitudinalmente e podem apresentar comprimentos da ordem de até milhares de quilômetros. Assim, é possível que os terrenos brasilianos do sudoeste goiano possuam continuidade longitudinal em direção a norte e a sul. As rochas metavulcânicas básicas a ácidas associadas a rochas graníticas encontradas às margens do Rio Araguaia entre as cidades de Aragarças e Aruanã (Drago et al. 1981) podem representar o prolongamento desses terrenos na direção NE, acompanhando, grosso modo, a direção do lineamento Transbrasiliano (Schobbenhaus Filho et al. 1975), como é mostrado no mapa da figura 13. Nesse mapa tentou-se traçar os limites das áreas de predomínio de rochas metaígneas brasilianas, o que configura um provável arco magmático do Proterozóico Superior. De acordo com os dados apresentados por Richardson et al. (1984a) e Richardson et al. (1984b), é possível que as rochas da seqüência vulcano-sedimentar de Mara Rosa, ao menos as da região de Chapada, também tenham-se originado no Ciclo Brasiliano, em um ambiente de arco de ilhas, como indicam as características químicas das rochas metavulcânicas que a constituem. Esses autores apresentam diversas isócronas $\mathrm{Rb}$ - $\mathrm{Sr}$ obtidas nessas rochas, que revelaram idades entre $561 \pm 6 \mathrm{Ma}$ e $532 \pm 1 \mathrm{Ma}$.

Os dados apresentados por Tassinari et al. (1981) indicam três províncias geocronológicas de rochas graníticas e gnáissicas brasilianas, nas regiões de Porto Nacional, Porangatu e Santa Fé-Jussara. A esta última pode ser adi-

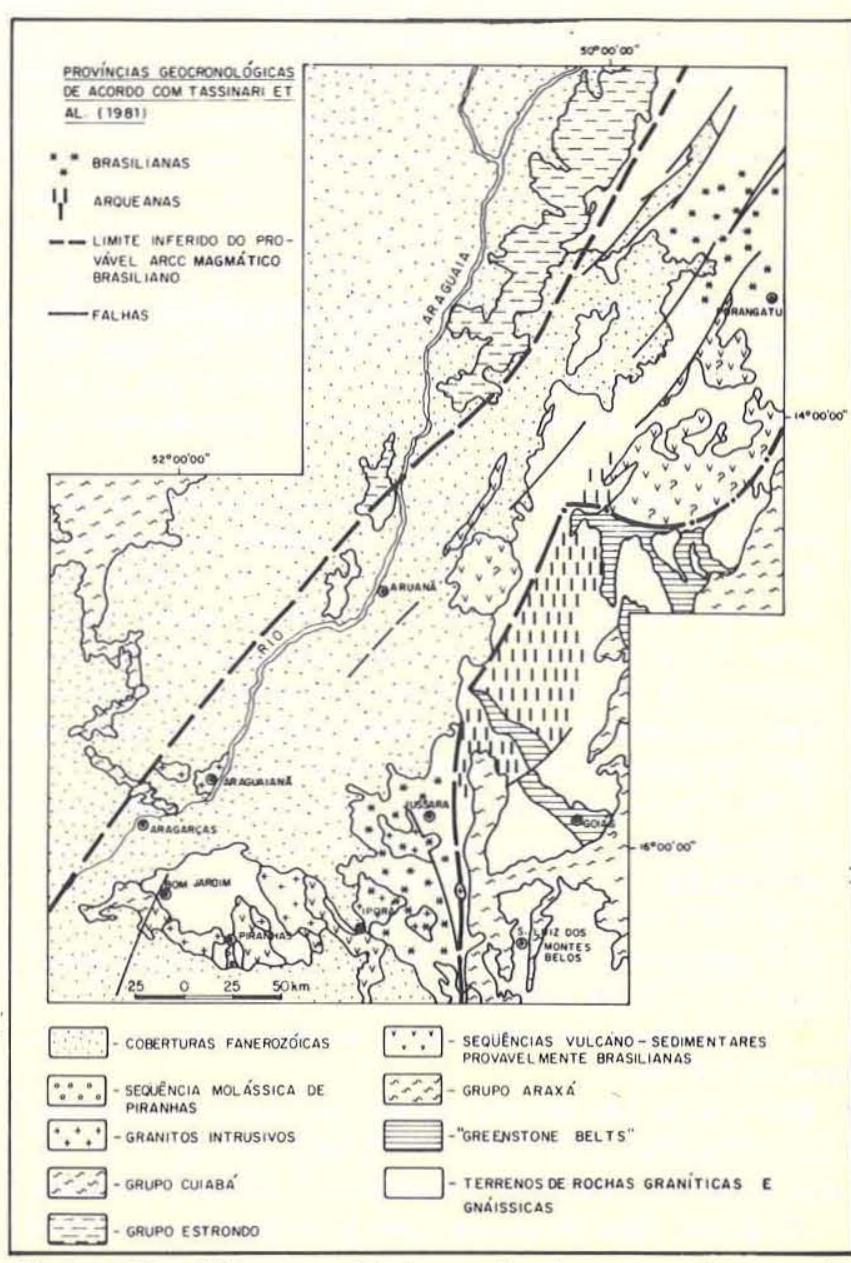

Figura 13 - Esboço geológico regional mostrando a provável faixa de atividade ignea brasiliana na região centro-oeste. Fonte: Mapa Geológico do Brasil e da Área Oceânica Adjacente Incluindo Depósitos Minerais. Escala 1:2.500.000 (DNPM 1981), com modificações

cionada a região de Arenópolis-Piranhas (Pimentel et al. 1985). Essas províncias perlongam o Lineamento Transbrasiliano, que se estende desde a região de Bom Jardim de Goiás seguindo em direção NNE rumo à porção norte do Estado de Goiás. Esse lineamento deve representar, portanto, um elemento importante na evolução geotectônica da região. $\mathrm{Na}$ área que se estende entre Gurupi,Porto Nacional e Pe dro Afonso,na porção norte de Goiás,Haralyi \& Hasui (1981) identificaram, acompanhando o Lineamento Tran'sbrasiliano, uma descontinuidade gravimétrica com forte mergulho para leste, que marca um possível limite entre blocos crustais distintos. Seguindo o esquema esboçado por Reis Neto (1983), esse lineamento pode representar uma zona de sutura entre duas massas continentais: o Cráton Amazônico a oeste e o chamado Maciço Mediano de Goiás a leste.

As semelhanças com cinturões pan-africanos As associações litológicas e as relações existentes entre elas, bem como alguns aspectos geoquímicos e isotópicos das rochas de cinturões pan-africanos (Hurley 1972, Frisch \& Al-Shanti 1977, Rogers et al. 1978, Gass 1982), especialmente o do nordeste do continente africano, são significativamente semelhantes às verificadas nos terrenos brasilianos da região sudoeste de Goiás. Alguns aspectos dessa semelhança podem ser aqui levantados: 
1. Em ambos os terrenos encontram-se:

a) Corpos graníticos de dimensões batolíticas de caráter calcialcalino, do tipo do granito do Rio Caiapó, compostos por variados tipos petrográficos (gabros a granitos). Um exemplo em um cinturão pan-africano é o do batólito de Ben Ghnema (Ghuma 1976, in Rogers et al. 1978) na Líbia, datado de 550 Ma pelos métodos $\mathrm{Rb}-\mathrm{Sr}$ e K-Ar, mostrando razão ${ }^{87} \mathrm{Sr} /{ }^{86} \mathrm{Sr}$ inicial entre 0,705 e 0,706 . b) Seqüências de rochas metavulcânicas e metapiroclásticas diferenciadas, de basaltos a riólitos, passando por andesitos e dacitos, quimicamente semelhantes a seqüências de arco de ilhas (Furnes et al. 1985).

c) Corpos graníticos circunscritos, pós-tectônicos, apresentando tendência alcalina. Exemplos pan-africanos são os chamados Younger Granites, no Egito, que mostram idades entre 580 e 588 Ma e razões iniciais entre 0,702 e 0,706. Química e isotopicamente, esses granitos são bastante semelhantes ao granito da Serra do Iran. A tabela 4 apresenta uma comparação entre os dados químicos e isotópicos desses granitos.

d) Seqüências compostas por metabasaltos associados a metapelitos, rochas carbonáticas e cherts, altamente deformadas e metamorfizadas em fácies anfibolito (Unidade Córrego Santo Antônio).

e) Migmatitos associados a terrenos gnáissicos metamorfizados em fácies anfibolito.

2. A cratonização em ambas as áreas ocorreu há aproximadamente $500 \mathrm{Ma}$.

3. Xistos azuis não são encontrados nas áreas consideradas, o que, de acordo com Gass (1982), pode indicar ter o cinturão evoluído a rartir de pequenos $(<700 \mathrm{~km})$ movimentos de placas, uma proposição que se enquadra bem dentro
Tabela 4 - Quadro comparativo das caracteristicas químicas e isotópicas dos Younger Granites, no Egito, associados à fase final de evolução do cinturão pan-africano no nordeste da África (Rogers et al. 1978), e do granito da Serra do Iran

\begin{tabular}{|l|c|c|}
\hline $\begin{array}{c}\text { FATOR } \\
\text { CONSIDERADO }\end{array}$ & $\begin{array}{c}\text { YOUNGER } \\
\text { GRANITES }\end{array}$ & $\begin{array}{c}\text { GRANITO DA } \\
\text { SERRA DO IRAN }\end{array}$ \\
\hline $\mathrm{SiO}_{2}(\%)$ & $76-72$ & $75-71$ \\
$\mathrm{MgO}(\%)$ & $0,08-0,58$ & $<0,50-0,60$ \\
$\mathrm{CaO}(\%)$ & $0,53-1,82$ & $0,61-1,64$ \\
$\mathrm{Na}_{2} \mathrm{O}+\mathrm{K}_{2} \mathrm{O}(\%)$ & $8,7-8,2$ & $9,59-8,22$ \\
$\mathrm{Rb}(\mathrm{ppm})$ & $214-112$ & $224-125$ \\
$\mathrm{Sr}(\mathrm{ppm})$ & $21-287$ & $9-261$ \\
$\left({ }^{87} \mathrm{Sr} / 86 \mathrm{Sr}\right)_{\mathrm{i}}$ & $0,702-0,706$ & 0,70499 \\
\hline Idade $(\mathrm{Ma})$ & $580-588$ & 564 \\
\hline
\end{tabular}

do modelo de multiarcos.

A semelhança entre as associações litológicas dos dois terrenos pode indicar uma similaridade entre os regimes tectônicos que as originaram. A origem dos cinturões pan-africanos tem sido atribuída a diversos processos, tais como extensão crustal, remobilização compressional, subducção de litosfera e colisão continental. Em resumo, esses processos podem ser incluídos dentro de duas hipóteses extremas. Uma advoga que esses cinturões se formaram pelo retrabalhamento de crosta continental mais antiga e a outra invoca processos de adição de material juvenil à crosta, pela subducção e posterior colisão de placas litosféricas. Embora algumas evidências em favor da primeira hipótese sejam levantadas, a segunda parece explicar com bastante propriedade a maioria das feições geológicas, geoquímicas e isotópicas encontradas tanto nos cinturões

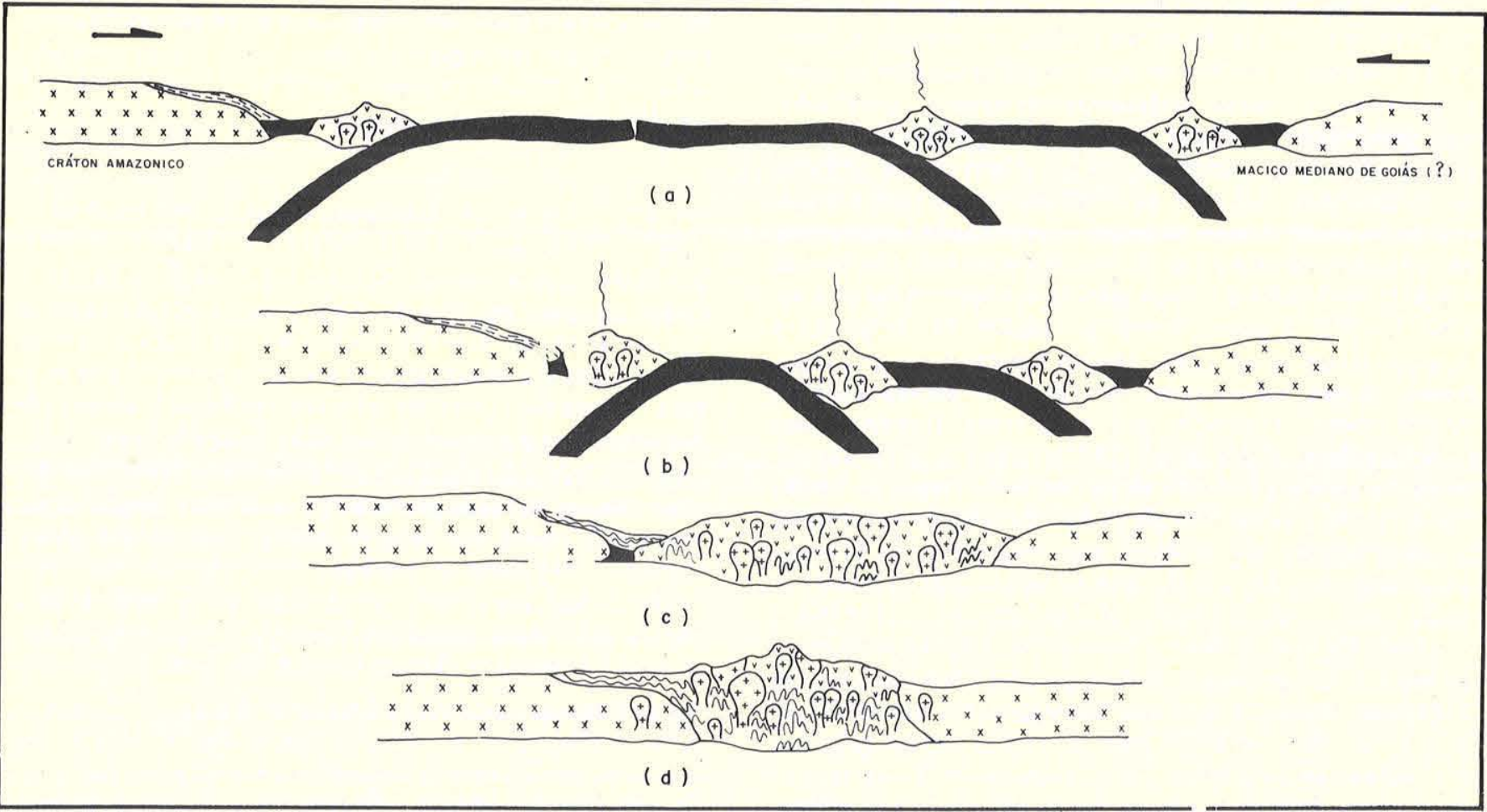

Figura 14 - Modelo hipotético para a evolução geotectônica da região sudoeste de Goiás: a) estabelecimento de arcos vulcânicos com a extrusão de basaltos toleiticos e concomitante intrusão de corpos gabro-dioriticos; b) extrusão de seqüências vulcânicas calcialcalinas e intrusão de pequenos corpos composicionalmente equivalentes; c) coalescência dos arcos com intrusões de corpos graníticos batoliticos, do tipo do Rio Caiapó; d) choque e junção das massas continentais seguidos de intrusões graniticas potássicas, pós-tectônicas, soerguimento, erosão e formação de depósitos molássicus 
pan-africanos, especialmente na parte nordeste do continente africano, como nos terrenos do sudoeste goiano. Assim, o modelo geotectônico da figura 14 - que representa esquematicamente a evolução geológica da região que se estende de oeste de Bom Jardim de Goiás até as vizinhanças de São Luís de Montes Belos e envolve o estabelecimento de um sistema de multiarcos entre duas massas continentais convergentes - é proposto para explicar a evolução dessa última região.

CONCLUSÕES As características litológicas aliadas às feições geoquímicas de elementos maiores e traços das rochas metavulcânicas e metaplutônicas associadas da Unidade Córrego da Onça da seqüência vulcano-sedimentar de Arenópolis sugerem que essa associação de rochas evoluiu em um ambiente geotectônico semelhante aos arcos magmáticos atuais. Essas semelhanças permitem que se proponha um modelo de tectônica de placas para explicar a evolução da seqüência vulcano-sedimentar de Arenópolis e dos terrenos brasilianos do sudoeste goiano, o que implica uma nova interpretação para a evolução do Ciclo Brasiliano no centro-oeste brasileiro. Admite-se, assim, que a referida seqüência tenha-se formado em um arco de ilhas, sobre uma zona de subducção, onde era consumida a litosfera oceânica que separava as duas massas continentais, as quais terminaram por se chocar e soldar no final do processo.

Agradecimentos Os autores agradecem ao professor Hardy Jost, pela leitura crítica do manuscrito e pelas sugestões que contribuíram para a melhoria do trabalho; e aos laboratórios de geoquímica da Universidade de Brasília e da Metais de Goiás S.A. (Metago S.A.), pelas análises químicas. $\mathrm{O}$ apoio financeiro foi proporcionado pelo Conselho Nacional do Desenvolvimento Científico e Tecnológico (CNPq) (Proc. 405501/82 e 403694/84) e pelo Programa de Auxílio ao Desenvolvimento Científico e Tecnológico (PADCT).

\section{REFERENCIAS BIBLIOGRAFICAS}

BARBOUR, A.P.; GIRARDI, V.A.V.; KAWASHITA, K.; SOUZA, A.M.S. - 1979 - Geologia do complexo máfico-ultramáfico alcalino de Santa Fé, Goiás. São Paulo. Inst. Geoc., USP, p. 11-18 (Bol. 10)

BAKOR, A.; GASS, I.G.; NEARY, C.R. - 1976 - Jabal al Wask, northwest Saudi Arabia:-an Eocambrian back-arc ophiolite. Earth Plan. Sci. Lett., 30:1-9.

BERNASCONI, A. - 1983 - The Archaean terranes of central eastern Brazil. A review. Precamb. Res., 232:107-131.

BERNASCONI, A. - 1984 - The nature, distribution and relationship of Archaean terranes in eastern Brazil. Rev. Bras. Geoc., 14(4):210-216.

CONDIE, K.C. - 1973 - Archean magmatism and crustal thickening. Geol. Soc. Am. Bull., 84:2981-2992.

DICKINSON, W.R. - 1981 - Plate tectonics through geological time. Phil. Trans. R. Soc. Lond., A301:207-214.

DRAGO, V.A.; PRADO, P.; BEZERRA, P.E.L.; SIMÕES, M.A.; PINTO, A.C.; MONTALVÃO, R.M.G.; TASSINARI, C.C.G. - 1981 - Contribuição ao estudo geológico do vale do Rio Araguaia. In: SIMP. GEOL. CENTRO-OESTE, 1, Goiânia, 1981. Atas... Goiânia, SBG, p. 404-421.

EVENSEN, N.M.; HAMILTON, P.J.; O'NIONS, R.K. - 1978 Rare-earth abundances in chrondritic meteorites. Geoch. et Cosmoch. Acta, 42:1199-1212.

FARIA, A.; FUCK, R.A.; VELOSO, J.A.V.; HIRSON, J.R.; ANDRADE, G.F.; FONSECA, M.R.C.B. - 1975 - Projeto Piranhas. DNPM/FUB, v. 1,143 p. (relatório final inédito).

FRAGOMENI, P.R.P. \& COSTA, S.A.G. - 1976 - Complexo vulcano-sedimentar de Bom Jardim de Goiás - base do Grupo Cuiabá. In: CONGR. BRAS. GEOL., 29, Ouro Preto, 1976. Resumos... Ouro Preto, SBG. Bol. 1, p. 11.

FRISCH, W. \& AL-SHANTI, A. - 1977 - Ophiolite belts and the collision of island arcs in the Arabian Shield. Tectonophysics, 43:293-306.

FURNES, H.; SHIMRON, A.E.; ROBERTS, D. - 1985 - Geochemistry of Pan-African volcanic arc sequences in southeastern Sinai Peninsula and plate tectonics implications. Prec. Research, 29:359-382.

GANA, P.F. \& HERVÉ, F.A. - 1983 - Geología del basamento cristalino en la cordillera de la costa entre los Ríos Mataquito y Maule, VII Región. Rev. Geol. Chile, 19-20:37-56.

GARCIA, M.O. - 1978 - Criteria for identification of ancient volcanic arcs. Earth Sci. Rev., 14:147-165.

GASS, I.G. - 1982 - Upper Proterozoic (Pan-African) calc-alkaline magmatism in north-eastern Africa and Arabia. In: R.S. THORPE ed. Andesites. N. York, Wiley, p. 591-609.

GILL, J.B. - 1981 - Orogenic andesites and plate tectonics. 1 st ed. Berlin, Springer-Verlag, $390 \mathrm{p}$.

HARALYI, N.L.E. \& HASUI, Y. - 1981 - Anomalias gravimétricas e estruturas maiores no sul de Goiás. In: SIMP. GEOL. CENTRO-OESTE, 1, Goiânia, 1981. Atas... Goiânia, SBG p. 79-90.
HERVÊ, F.A.; KAWASHITA, K.; MUNIZAGA, F.; BASEI, M.A.S - 1984 - Rb-Sr isotopic ages from late Paleozoic metamorphic rocks of central Chile. J. Geol. Soc. Lond., 141:877-884.

HURLEY, P.M. - 1972 - Can the subduction process of mountain building be extended to Pan-African and similar orogenic belts? Earth Plan. Sci. Lett., 15:305-314.

IANHEZ, A.C.; PITTHAN, J.H.L.; SIMÕES, M.A.; DEL'ARCO, J.O.; TRINDADE, C.A.H.; LUZ, D.S.; FERNANDES, C.A.C.; TASSINARI, C.C.G.; SOUZA, J.J.; FREIRE, F.A.; OLIVEIRA, F.C.; SILVA, R.H.; BONOW, C.W.; MOREIRA, H.L. 1983 - Geologia. In: PROJETO RADAMBRASIL. Folha SE. 22 Goiânia. Rio de Janeiro (Lev. Rec. Nat. 31).

IANHEZ, A.C.; SIMÕES, M.A.; LUZ, D.S. - 1984 - Grupos Dois Irmãos e Amorinópolis - duas novas seqüências vulcano-sedimentares no sudoeste de Goiás. In: CONGR. BRAS. GEOL. 33, Rio de Janeiro, 1984. Anais..., Rio de Janeiro, SBG. p. $2577-2589$.

IRVINE, T.N. \& BARAGAR, W.R.A. - 1971 - A guide to the chemical classification of common volcanic rocks. Can. J. Earth Sci., 8:523-548.

JAKES, P. \& GILL, J. - 1970 - Rare earth elements and the island arc tholeiitic series. Earth Plan. Sci. Lett., 9:17-28.

KARIG, D.E. \& SHARMAN, G.F. - 1975 - Subduction and accretion in trenches. Bull. Geol. Soc. Am., 86:377-389.

KUNO, H. - 1968 - Differentiation of basalt magmas. In: H.H HESS \& A. POLDERVAART eds. Basalts, N. York, Wiley. p. 623-688.

MARQUES, V.J.; GUIMARÃES, M.T.; COSTA, S.A.G. - $1980-$ Aplicação de estudos petroquímicos à pesquisa mineral de suítes vulcanogênicas em Bom Jardim de Goiás. In: CONG. BRAS. GEOL., 31, Camboriú, 1980. Anais... Camboriú, SBG. p. 2082-2103

MIYASHIRO, A. - 1973 - The Troodos ophiolitic complex was probably formed at an island arc. Earth Plan. Sci. Lett., 19 218-224.

MIYASHIRO, A. - 1975a - Classification, characteristics and origin of ophiolites. J. Geol., 83:249-281.

MIYASHIRO, A. - $1975 \mathrm{~b}$ - Volcanic rock series and tectonic setting. Ann. Rev. Earth Sci., p. 251-259.

PEARCE, J.A. - 1975 - Basalt geochemistry used to investigate past tectonic environments on Cyprus. Tectonophysics, 25 : 41-67.

PEARCE, J.A. - 1976 - Statistical analysis of major element patterns in basalts. J. Petrol., 17(1):15-43.

PEARCE, J.A.; ALABASTER, T.; SHELTON, A.W.; SEARLE, M.P. - 1981 - The Oman ophiolite as a Cretaceous arc-basin complex: evidence and implications. Phil. Trans. R. Soc. Lond., A300:299-317.

PEARCE, J.A. \& CANN, J.R. - 1973 - Tectonic setting of basic volcanic rocks determined using trace element analysis. Earth 
Plan. Sci. Lett., 19:290-300.

PEARCE, T.H.; GORMAN, B.E.; BIRKETT, T.C. - 1975 - The $\mathrm{TiO}_{2}-\mathrm{K}_{2} \mathrm{O}-\mathrm{P}_{2} \mathrm{O}_{5}$ diagram: a method of discriminating between oceanic and non-oceanic basalts. Earth Plan. Sci. Lett., 24: 419-426.

PENA, G.S. \& FIGUEIREDO, A.J.A - 1972 - Projeto Alcalinas. Geologia das folhas de Iporá, Amorinópolis, Piranhas, Caiapônia no sudoeste de Goiás. DNPM/CPRM, v. 1, 143 p. (relatório inédito).

PIMENTEL, M.M. - 1985 - A seqüência vulcano-sedimentar de Arenópolis, GO; petrologia ígnea e metamórfica, contexto geotectônico e considerações metalogenéticas preliminares. Brasília, 187p. (Dissertação de Mestrado, Universidade de Brasília).

PIMENTEL, M.M. \& FUCK, R.A. - 1986 - Geologia da seqüência vulcano-sedimentar de Arenópolis, Goiás. Rev. Bras. Geoc., 16(2):217-223.

PIMENTEL, M.M.; FUCK, R.A.; CORDANI, U.G.; KAWASHITA, K. - 1985 - Geocronologia de rochas graníticas e gnáissicas da região de Arenópolis-Piranhas, Goiás. Rev. Bras. Geoc., $15(1): 3-8$.

REIS NETO, J.M. - 1983 - Evolução geotectônica da bacia do Alto Tocantins, Goiás. São Paulo, 98 p. (Dissertação de Mestrado, IG-USP).

RICHARDSON, S.V.; KESLER, S.E.; ESSENE, E.J. - 1984a Origin and geochemistry of the Chapada Cu-Au deposit, Goiás, Brazil: a metamorphosed wall-rock porphyry copper. s.l., 16 p. (Manuscrito inédito).

RICHARDSON, S.V.; JONES, L.M.; KESLER, S.E. - 1984b Strontiun isotopic geochemistry of early cambrian rocks of the Chapada deposit, Goiás, Brasil. s.1., 16 p. (manuscrito inédito).

ROGERS, J.J.W.; GHUMA, M.A.; NAGY, R.M.; GREENBERG,
J.K.; FULLAGAR, P.D. - 1978 - Plutonism in Pan-african belts and the geologic evolution of northeastern Africa. Earth Plan. Sci. Lett., 39:109-117.

ROSITO, J.; FIGUEIREDO, A.J.A.; PENA, G.S. - 1971 - Nota preliminar sobre uma nova formação pré-devoniana no sudoeste de Goiás. In: CONGR. BRAS. GEOL., 25, São Paulo, 1971. Resumo das Comunicações... São Paulo, SBG. p. 169-170.

SCHOBBENHAUS FILHO, C.; RIBEIRO, C.L.; OLIVA, L.A.; TAKANOHASHI, J.; LINDENMAYER, Z.G.; VASCONCELOS, J.B.; ORLANDI, V. - 1975 - Carta geológica do Brasil ao milionésimo. Folha Goiás (SD.22). Brasília, DNPM, $114 \mathrm{p}$.

SEER, H.J. - 1985 - Geologia, deformação e mineralização de cobre no complexo vulcano-sedimentar de Bom Jardim de Goiás. Brasília, 180p. (Dissertação de Mestrado, Universidade de Brasília).

SEER, H.J. \& NILSON, A.A. - 1986 - Contribuição à geologia das unidades pré-cambrianas da região de Bom Jardim de Goiás. In: SIMP. GEOL. CENTRO-OESTE, 2, E soiânia, 1985. Atas... Goiânia, SBG. p. 267-281.

TASSINARI, C.C.G.; SIGA Jr., O.; TEIXEIRA, W. - 1981 Panorama geocronológico do centro-oeste brasileiro: soluções, problemática e sugestões. In: SIMP. GEOL. CENTRO-OESTE, 1, Goiânia, 1981. Atas..., Goiânia, SBG. p. 93-113.

THIELE, R.C. \& HERVÉ, F.A. - 1984 - Sedimentación y tectónica de antearco en los terrenos preandinos del Norte Chico, Chile. Rev. Geol. Chile, 22:61-75.

\section{SOCIEDADE BRASILEIRA DE GEOLOGIA SOCIEDADE BRASILEIRA DE PALEONTOLOGIA}

\section{SIMPÓSIO SOBRE A EVOLUÇÃO DO ATLÂNTICO SUL}

23 e 24 de julho de 1987

Local: Auditório do Edifício Sede da Petrobrás, Rio de Janeiro, RJ

Próximo número da Revista Brasileira de Geociências: Anais do I Simpósio sobre a Evolução do Atlântico Sul 